GET UP AND GO: EVALUATING STATION AREA FACTORS AFFECTING A.M. COMMUTER RAIL BOARDINGS IN THE GREATER TORONTO AND HAMILTON AREA

\author{
by \\ Graham Lee Procter \\ Bachelor of Arts, University of Calgary, 2013 \\ A Major Research Paper \\ presented to Ryerson University \\ in partial fulfillment of the requirements for the degree of \\ Master of Planning \\ in \\ Urban Development
}

Toronto, Ontario, Canada, 2016

(c) Graham Lee Procter, 2016 


\section{$\underline{\text { Author's Declaration for Electronic Submission of MRP }}$}

I hereby declare that I am the sole author of this MRP. This is a true copy of the MRP, including any required final revisions.

I authorize Ryerson University to lend this MRP to other institutions or individuals for the purpose of scholarly research.

I further authorize Ryerson University to reproduce this MRP by photocopying or by other means, in total or in part, at the request of other institutions or individuals for the purpose of scholarly research.

I understand that my MRP may be made electronically available to the public. 


\title{
GET UP AND GO: EVALUATING STATION AREA FACTORS AFFECTING A.M. COMMUTER RAIL BOARDINGS IN THE GREATER TORONTO AND HAMILTON AREA
}

\author{
(c) Graham Lee Procter, 2016 \\ Master of Planning \\ In \\ Urban Development \\ Ryerson University
}

\section{$\underline{\text { Abstract }}$}

This research evaluates built form and demographic factors of GO Transit commuter rail station areas that contribute to ridership and utilization of existing services in the A.M. peak period using biannual GO Rail ridership information from the Spring of 2010 to Spring of 2015. In order to identify predictors of ridership growth, four regression models were estimated that evaluated factors affecting cross-sectional ridership, cross-sectional utilization of capacity, station-level utilization at each time period, and station-level year-over-year utilization growth. Results indicate that the strongest predictors of ridership, utilization, and growth were station parking capacity and household density of the surrounding area. This suggests potential for tensions in developing GO-supportive station-area land use policy strategies focused on either expanding station-area parking capacity or station-area residential intensification. The stationlevel utilization model produced a priority list of future service increases on GO Rail corridors based on existing capacity and ridership.

An article on transit planning in the Greater Toronto and Hamilton, used the key words: planning, transit, quantitative analysis 


\section{$\underline{\text { Acknowledgements }}$}

I would like to thank my family who, from afar, were always supportive and willing to listen to me vent for hours about planning issues that were, most likely, exceedingly uninteresting to them. I would like to thank my friends who always saw the value in taking a few hours off to mentally decompress and check out a new restaurant across town or made themselves available to bounce ideas off of.

I would also like to thank my supervisor, Dr. Matthias Sweet, for his guidance and patience for a student who, despite an extreme interest in transit and data analysis, had to be helped out with simple statistical programming operations at multiple times throughout the semester. Dr. Sweet is extremely talented, very supportive, and is pushing students and the school in a great direction and I was honoured to have been among the students under his supervision at Ryerson University. I would also like to thank the rest of the faculty at the School of Urban and Regional Planning for selecting me to be a part of this fantastic program and also for their encouragement throughout my two years wandering the halls and frequenting computer labs. I would like to especially thank Dr. Raktim Mitra for agreeing to be the second reader for this paper and being a source of insight during my time at Ryerson.

Strangely, I would also like to thank Toronto. This is a beautiful, diverse, and stimulating city that is also gritty, grey, and gridlocked but I wouldn't have it any other way. There's real, "big city" challenges here that may seem like intractable problems to others but they strike me more as exciting opportunities that we are rather lucky to have and I am thrilled to try and tackle these challenges with my unbelievably driven classmates and future coworkers. 
Dedicated to my father 


\section{Table of Contents}

Author's Declaration for Electronic Submission of MRP ......................................................ii

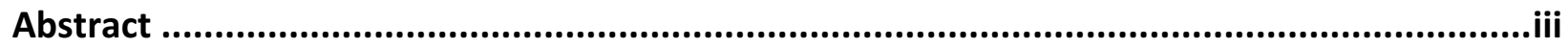

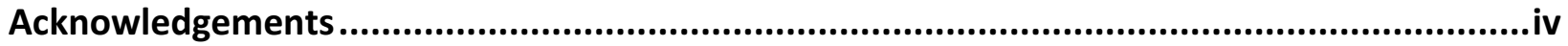

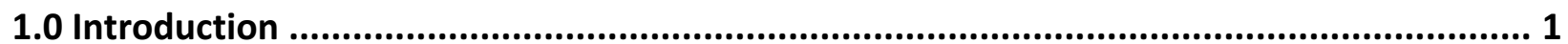

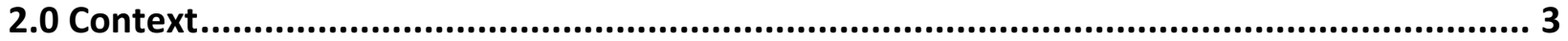

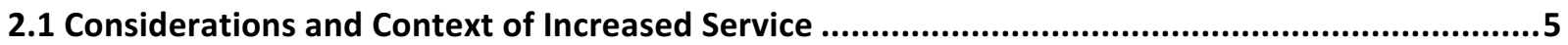

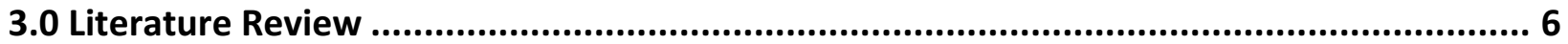

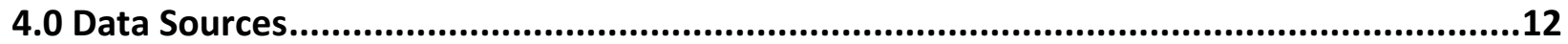

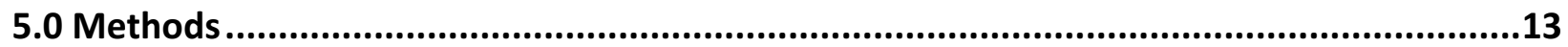

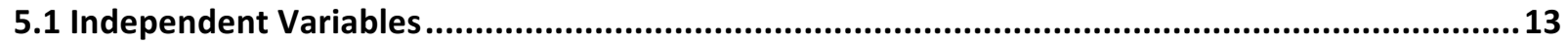

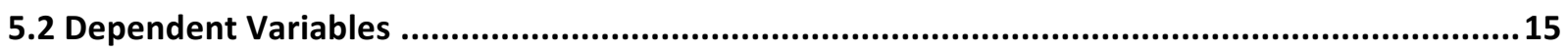

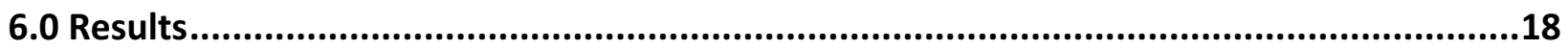

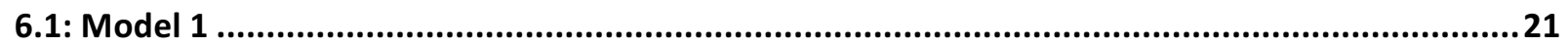

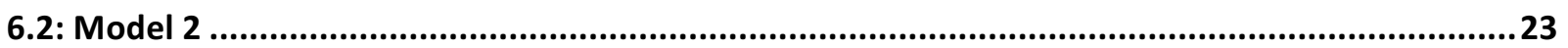

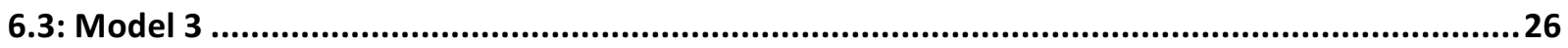

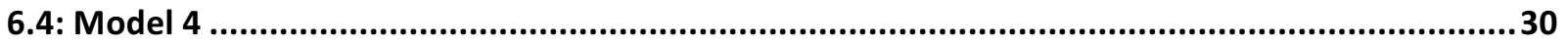

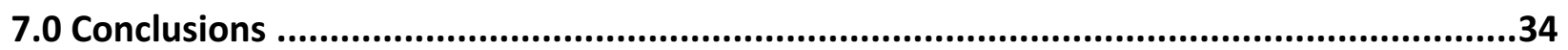

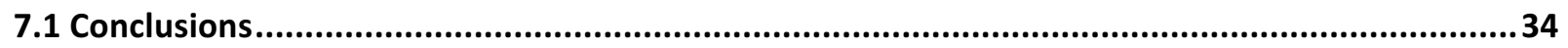

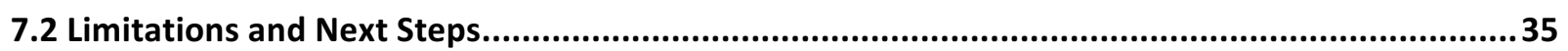

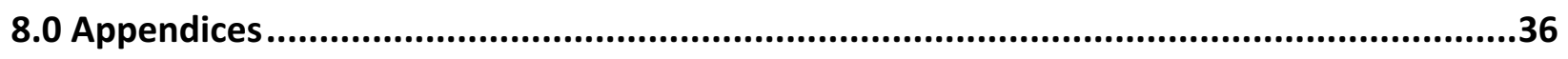

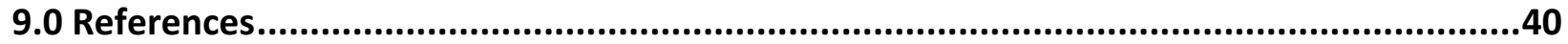




\section{$\underline{\text { List of Tables }}$}

Table 1: Significant Factors from Academic Literature …………….......................................... 7

Table 2: Variables Included in the Regression Models Including Predicted Coefficient Signs and

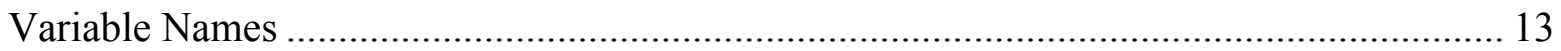

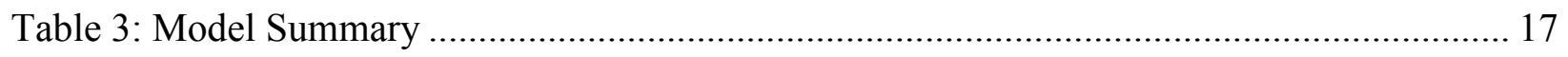

Table 4: Output of Average Ridership Model (Model 1) .............................................................. 22

Table 5: Output of Average Utilization Model (Model 2).......................................................... 24

Table 6: Output of Station-level Utilization Rate Model (Model 3) .............................................. 26

Table 7: Output of Station-level Year-over-year Utilization Change Model (Model 4) ............... 31

\section{$\underline{\text { List of Figures }}$}

Figure 1: Map of the Greater Toronto and Hamilton Area (Metrolinx, 2016) ............................... 3

Figure 2: Map of GO Rail Network (GO Transit, 2016) ................................................................ 4

Figure 3: Growth in Boardings at GO Rail stations excluding Union Station.............................. 18

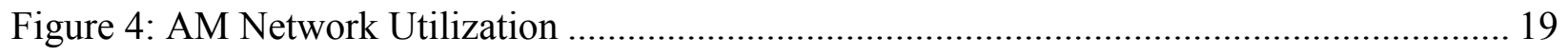

Figure 5: Seats Offered on GO Rail in the AM Peak ................................................................. 19

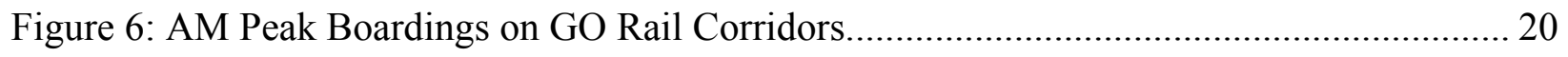

Figure 7: Lakeshore East and West All-Day Boardings ............................................................... 20

Figure 8: Lakeshore East and West All-Day Capacity ……………………………………......... 21

Figure 9: Residual Plot of Average Ridership Model (Model 1)................................................ 22

Figure 10: Residual Plot of Average Utilization Model (Model 2) ............................................ 25

Figure 11: Residual Plot of Station-level Utilization Rate Model (Model 3)............................... 29

Figure 12: Residual Plot of Station-level Year-over-year Utilization Change Model (Model 4) 32

\section{$\underline{\text { List of Appendices }}$}

Appendix 1 Station Capacity in Cordon Count Years...................................................................... 36

Appendix 2: Station Profiles for GO Rail Stations ………….................................................... 38 


\subsection{Introduction}

The Greater Toronto and Hamilton Area is one of the fastest growing regions in North America adding an additional 100,000 residents annually who must all travel about the region for employment, education, recreation, or leisure which adds considerably more strain on already over-burdened transportation system. Significant barriers exist to expanding road capacity in the GTHA including space constraints, strained municipal budgets, and growing support amongst the public and policy makers for investment into transit improvements and alternative travel modes.

The Government of Ontario has announced a commitment to provide \$15 billion in funding for regional transit projects that will connect population and employment centres across the region (Metrolinx, 2014). A portion of this funding will support the development of two-way, all day, 15-30 minute regional rail service on existing rail corridors within the GTHA with the goals of increasing the attraction of regional transit, shifting travel demand away from automobiles, easing traffic congestion, and increasing regional transit ridership through increased service frequency and capacity.

This plan, called Regional Express Rail (RER), involves increasing service on existing corridors rather than building new infrastructure to accommodate an increased level of regional rail service. The long timelines and expense of constructing new transit infrastructure provides an opportunity for more frequent and flexible two-way service increases to form the backbone of the regional transit network using corridors that can accommodate more rail trips and passenger capacity.

This increase in level of service will be coordinated by Metrolinx, the agency responsible for regional transit planning of bus and rail services, and delivered by the agency's operating division, GO Transit. Currently, only three of the seven rail corridors in the GTHA offer service beyond the A.M. and P.M. peak periods and the changes proposed in the RER plan will represent a substantial increase in level of service for the GO Rail network. The detailed description of the phasing of RER and its integration with other transit projects is discussed in Metrolinx's regional transportation plan The Big Move.

But what can be done to ensure new capacity and more frequent service translates into new riders? Maximizing the ridership gains from increased service requires an examination of 
commuter rail station areas to determine what creates a transit-supportive area and what land use policies can increase the ridership gains of new service. To this end, this research will address two key questions:

- What are the external conditions that exist around stations that make them more responsive to increases in service frequency?

- Which corridors and stations are more responsive to increases in service frequency independent of external conditions?

Service frequency increases that do not require large capital investments such as building new high-cost heavy rail corridors can be deployed relatively easily. Therefore, building an understanding of which corridors and station areas are more responsive to transit service increases can inform the deployment of more frequent service by a transit agency and can also spur local land use planning initiatives that create responsive station areas. Understanding which corridors would be more likely to benefit from increased service would also assist in developing a ranking of which corridors should be a priority to receive new service capacity.

To answer these questions statistical models were developed that explore the demographic and built form factors of areas surrounding transit stations that influence ridership. Once the station area factors that are significant to ridership growth are explored and controlled for in the context of commuter rail service in the GTHA, the outputs from the models can begin to explain the relative impact of certain demographic and built form factors. This can inform local land use policy in order to create more favourable conditions around transit stations that more effectively generate new ridership from service increases. 


\section{$\underline{\text { 2.0 Context }}$}

The Greater Toronto and Hamilton Area covers over $7000 \mathrm{~km}^{2}$ and is home to more than 6.5 million residents making it the most populous in Canada and third most populous in North America. The region stretches along the north shore of Lake Ontario from Hamilton in the west to Oshawa in the east and north to Barrie on the southwest shore of Lake Simcoe. Toronto, and specifically downtown Toronto, is the economic hub of the region that accounts for nearly 20 percent of all employment in the GTHA (Data Management Group, 2011).

Figure 1: Map of the Greater Toronto and Hamilton Area (Metrolinx, 2016)

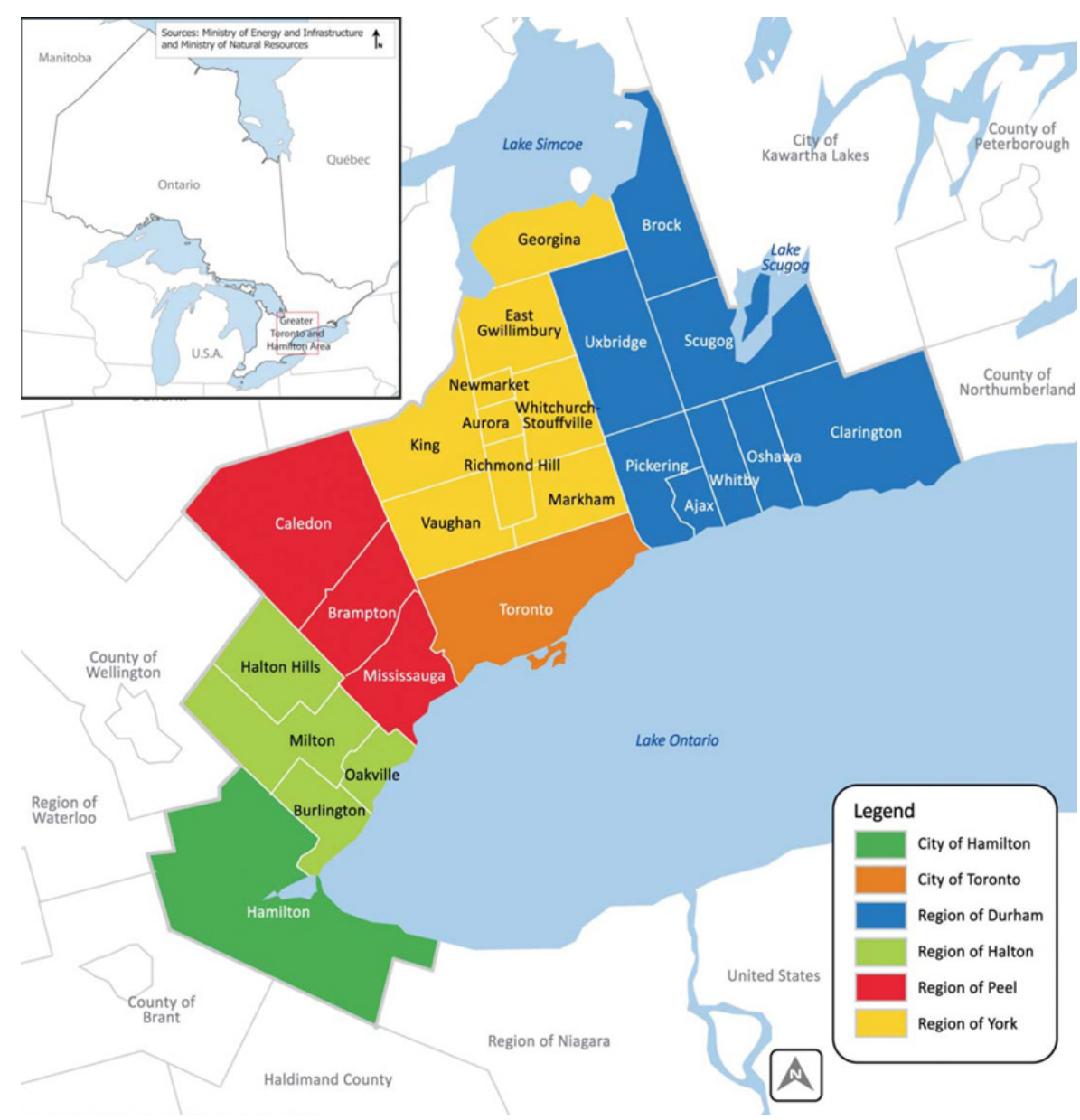

In 1967, facing increasing development along the lakeshore and congestion on the main highways into downtown Toronto from the west and east, the Government of Ontario began to 
run heavy rail commuter trains from Oakville to Pickering via downtown Toronto along the rail corridor near the lakeshore then owned by the Canadian National Railway. Expansion of the system along the lakeshore and to other corridors and regional centres has taken place with the Greater Toronto Transit Authority, now Metrolinx, purchasing tracks from Canadian National and Canadian Pacific. The GO Rail network today consists of seven corridors that connect terminals in Hamilton (Lakeshore West), Milton, Kitchener, Barrie, Richmond Hill, Lincolnville (Stouffville), and Oshawa (Lakeshore East) with Union Station and downtown Toronto. Figure 2 shows a representation of the GO Rail Network.

Currently, the Lakeshore East and West corridors provide AM peak, midday, PM peak, and evening two-way service at a minimum 30-minute frequency with more frequent AM and PM peak service. A portion of the Kitchener line provides midday two-way service on a 60minute frequency as of October 2015 in addition to more frequent AM and PM peak service (Kalinowski, 2015). The other four corridors offer commuter rail service whereby inbound trips occur only in the AM peak and outbound trips only in the PM peak with bus service operating during off-peak times. The RER plan to have two-way all day service on these corridors represents a very significant increase in level of service and frequency. There are 63 GO Rail stations along these seven corridors that exist in a vast diversity of contexts from dense urban areas, to large format retail zones, to industrial areas, to smaller exurban or rural municipalities. Many stations areas are also served by surface or structured parking.

Figure 2: Map of GO Rail Network (GO Transit, 2016)

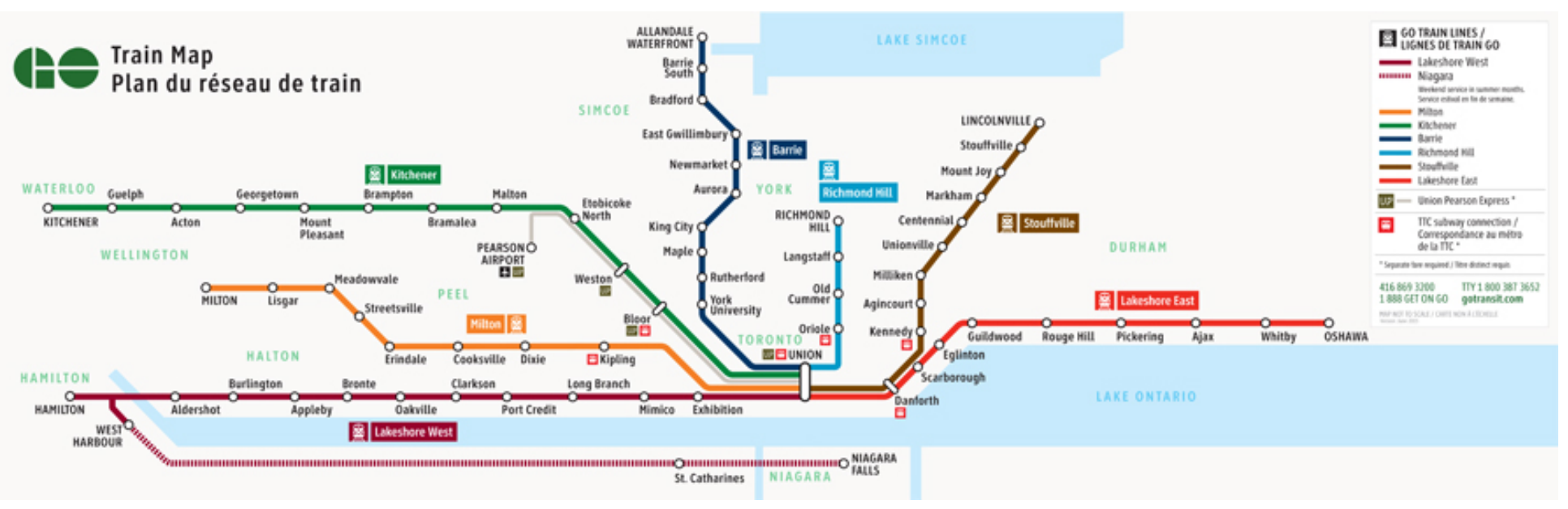




\subsection{Considerations and Context of Increased Service}

Metrolinx is responsible for planning and regional transit in the GTHA and working with local transit agencies, municipalities, and other stakeholders to best serve the region. Their regional transportation plan The Big Move describes how regional transit service is to help alleviate congestion and connect destinations with all-day, two-way service. Metrolinx, through GO Transit, will plan, coordinate, and deliver all future service increases and other regional transit projects.

Local municipal governments are responsible for land use planning in their jurisdictions and will develop station area plans that capitalize on an increased level of service to most effectively advance strategic priorities. Corridor expansions will require extensive consultation with municipalities and the public to ensure the negative impacts of construction and increased service are minimized for surrounding residents.

Any plan to increase service on existing GO Rail corridors must have regard to the other users of the corridor, namely the Canadian National Railway and the Canadian Pacific Railway who operate freight service on six of the seven rail corridors in the GTHA. These railway companies are under the federal jurisdiction of Transport Canada and must be consulted on any changes to GO Transit service as it directly affects their use of finite rail corridor space.

There are also several provincial plans and policies that address the how to benefit from increased transit service. The Growth Plan for the Greater Golden Horseshoe encourages more compact development around Growth Centres that are typically centred around major transit hubs or GO Rail stations (Government of Ontario, 2006). The Ministry of Transportation for Ontario (MTO) has drafted a set of guidelines for successful transit supportive communities that describes how land use policy and built form can impact transit ridership and create communities that are more likely to benefit from an increase in the level of transit services (MTO, 2012). These guidelines are for planning agencies to encourage station access and connectivity and to support development of residential and employment areas in close proximity to transit stations.

The regional transportation plan, The Big Move, also discusses the transformation of many station areas into "Mobility Hubs" that feature transit-oriented development patterns and connections to local transit and alternative modes such as walking and cycling. Many of these hubs match "Growth Centres" defined in the Growth Plan for the GGH and are targeted for increased density and transit service through the RER plan. 


\subsection{Literature Review}

Previous research has evaluated the built form and demographic factors that affect transit ridership. Studies that looked specifically at North American cities and transit systems were of particular interest to this research however some international studies were included for their similar methodology and factors found to be significant. Regression analysis was the dominant form of evaluation in these studies using multiple linear regression including residual analysis tests for to support conclusions drawn from this research.

While many articles evaluated subway, light rail, or bus transit, the factors found to be significant can apply in some form to commuter rail services and were considered as potential factors in this research. Each article presented a list of potential factors to be included in their models followed by a list of the factors that were found to be significant. Table 1 presents an overview of the significant factors that were determined from previous research on this topic. Significant factors were evaluated for their relevance to the case of commuter rail service in the GTHA and the availability of data to produce a set of variables to be included in this research. 
Table 1: Significant Factors from Academic Literature

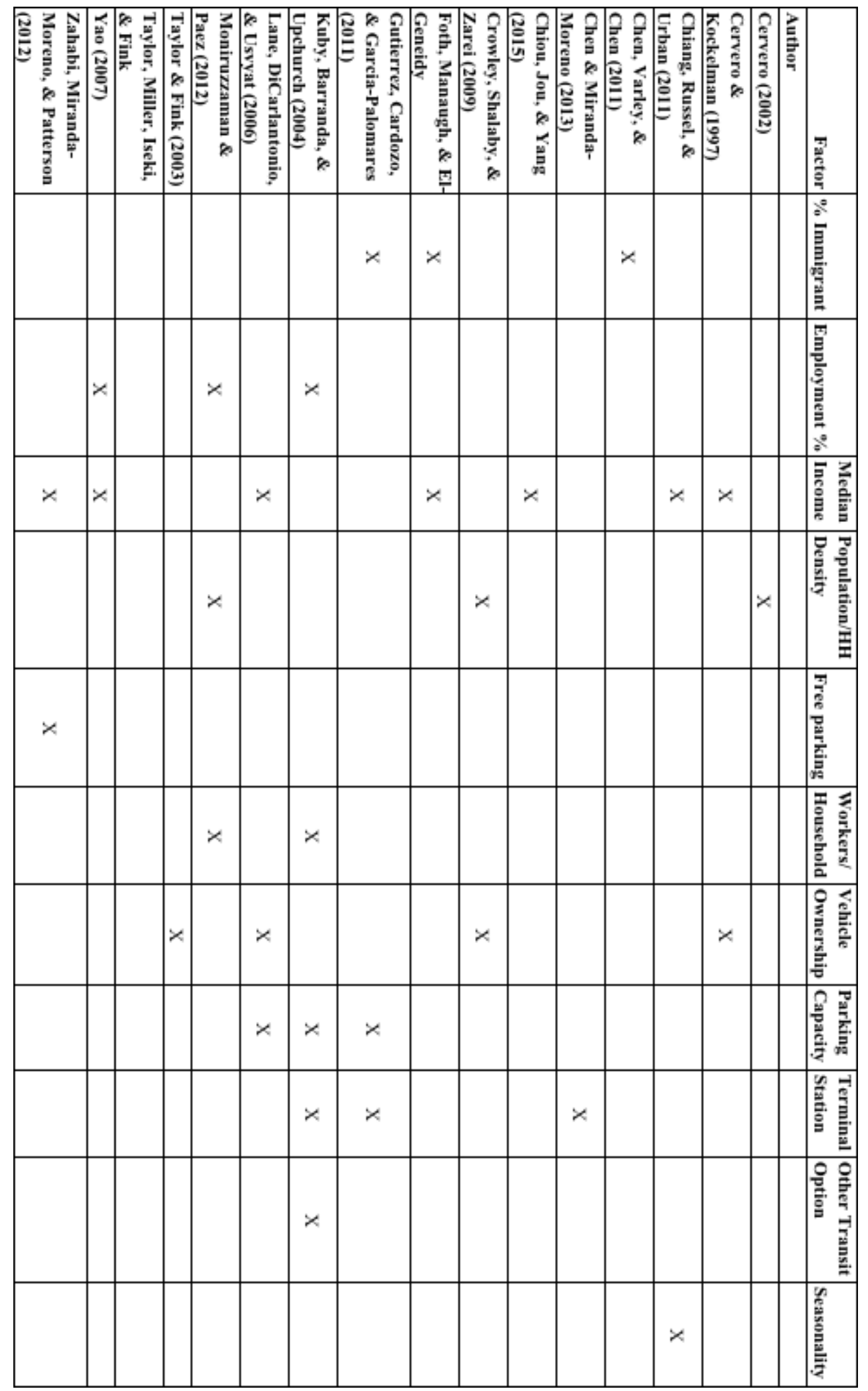




\section{Percent of Surrounding Population that are Recent Immigrants}

Previous studies have related recent immigrant status to a higher likelihood of taking transit thus making stations with higher proportions of immigrants or new Canadians more likely to take public transit. Foth, Manaugh, and El-Geneidy (2014) combined proportion of recent immigrants with percent of populations spending greater than 30 percent of their income on housing and percent unemployed to create an index of low-income that was found to be a significant factor in their analysis of transit demand in Toronto.

Similarly, Chen, Varley, and Chen (2011) related recent immigrant status to lower incomes and higher unemployment. These factors were combined to a form a social inequality index in an explanatory ridership model of the New York City subway. For the purposes of this research the proportion of residents identifying as immigrants in the surrounding station area was used as a potential explanatory variable.

\section{Employment Rate/Workers per Household}

Many previous studies uncovered strong links between employment and transit ridership of a station area. In several cases, notably Moniruzzaman and Paez (2012) and Kuby, Barranda, and Upchurch (2004), it was the job or employment opportunities within a station area that were found to be significant measured through total job numbers or employment density. Yao's 2007 study of Atlanta, GA concluded that the employment rate of the station area was significant to transit ridership. This measure, as well as workers per household in the surrounding station area, was seen to be more explanatory of station boardings for commuter rail and was considered in this research.

\section{Median Income}

Median income of a station area was also found to be a significant explanatory variable of transit ridership. Studies have negatively related income to vehicle ownership and have also related lower incomes to higher transit ridership in geographic areas (Cervero \& Kockelman, 1997). Zahabi, Mirando-Moreno, and Patterson (2012) found income to be statistically significant to explaining the variation in transit ridership in their study of commuter rail in Montreal. A lower income was positively associated with transit ridership of neighbourhoods with commuter rail service after accounting for residential self-selection biases of higher income 
residents choosing to locate in areas well-served by transit. Chiou, Jou, and Yang (2015) also concluded that a lower median income was significant in explaining transit ridership through a geographically weighted regression model decreased the effect of a variable based on the distance from a transit station that it was measured.

As with the variable derived from proportion of residents identifying as immigrants, income was combined with other factors to form indices of social need or inequality that were found to be significant in research by Foth et al. (2014). Lane, DiCarlantonio, and Uyvat (2006) found income to be a significant factor in their study of 17 US metropolitan region's demographic factors and overall transit ridership. This presents significant empirical evidence for including median income as a predictive factor of transit ridership.

Commuter rail services may be affected differently by income than local public transit trips however. While median income has been demonstrated to have a negative relationship with transit mode share, evidence exists that shows higher income individuals tend to make more trips on average than lower income households (Badoe and Miller, 2000). Additionally, the cost of a commuter rail trip is generally higher than local transit thus a higher income would be expected to increase the number commuter rail trips taken.

\section{Population Density/ Household Density}

The population density within a station area as well as metropolitan-level population density has been shown to strongly correlate to transit ridership. Thompson and Brown (2006) demonstrated a correlation between metropolitan density and transit ridership growth from 19902000 in US metropolitan areas with over 500,000 residents. Moniruzzaman and Paez (2012) and Crowley, Shalaby and Zarei, (2009) concluded that population density of census tracts and dissemination areas within close proximity to transit stations was significant in explaining transit ridership. Yao (2007) also concluded that population density was significant by including it with percent of low income residents within traffic analysis zones (TAZs) to form a "need index". Cervero (2002) also demonstrated a relationship between population density and transit ridership of origin and destination TAZs. Population density was expected to have a positive relationship to transit ridership and was included in this research. Household density was also included in this research to account for differences in built form and housing styles and within station areas. 


\section{Free Parking at Work}

The higher cost of parking at a trip destination correlates to higher transit ridership in a 2012 study of commuter rail by Zahabi et al. While determining the exact parking price for workers in an area would be extremely difficult, a measure exists that defines if an employee has free parking or not at their place of work. This measure was included as a proportion of workers in an area who have access to free parking.

\section{Vehicle Ownership}

Level of vehicle ownership would intuitively affect transit ridership as residents have another choice for mobility which would affect transit's share of overall trips. Due to the nature of the North American built environment, ownership of a vehicle affords flexibility and access that is preferable for residents even after accounting for maintenance and vehicle costs (Taylor $\&$ Fink, 2003). Vehicle ownership was found to be a significant factor in many studies and was included as an independent regression variable in a variety of different ways. Cervero \& Kockelman (1997) used the average number of vehicles in a household as a measure for vehicle ownership while Lane et al. (2006) used the proportion of households with 0 cars/households with access to a car as a measure for vehicle ownership. In both studies these factors were found to be significant and a measure of vehicle ownership was included in this research.

\section{Parking Capacity}

The commuter rail system in the GTHA serves primarily suburban and exurban areas therefore the findings by Gutierrez, Cardozo, and Garcia-Palomares (2011) that transit ridership at suburban transit stations is dependent on the supply of parking is significant. Lane et al. (2006) similarly concluded that parking supply at stations is an important driver of commuter rail services. GO Transit offers free parking at many stations and can respond to parking demands by constructing new parking facilities or acquiring the use of nearby lots to ensure an adequate supply is maintained. The supply of parking at each station should be included as a factor that is evaluated for its effect on GO Rail station ridership as many residents access the system by car and the availability of parking may affect their decision to park and ride or simply drive to their destination. 


\section{Terminal Station}

Terminal stations are expected to produce higher ridership because of their larger catchment areas and generally higher connectivity to other modes of transportation. Kuby et al. (2004) found terminal and interchange stations, evaluated as a dummy variable of 1 or 0 , to be significant to their study of light rail ridership and demonstrated that if a station is a terminal it can experience significantly more boardings per day than an inline station with similar demographic and built form characteristics.

Gutierrez et al. (2011) expanded on this method by including a dummy variable for terminal stations as well as a variable for the number of other lines that pass through interchange stations. Chen \& Miranda-Moreno (2013) also included a terminal station dummy variable in their analysis of the Montreal metro system that proved to be a statistically significant predictor of station ridership. Due to the few interchanges between commuter rail lines, a simple dummy variable was developed to capture the impact of terminal stations on ridership in this research.

\section{Other Rapid Transit Options}

Having other transportation options can negatively affect transit ridership, such as vehicle ownership. However, having a choice among different transit options will also affect the ridership on these duplicate services as some riders may be willing to substitute longer travel times for a lower fare. Kuby et al. (2004) included a dummy variable of centrality in their study of LRT ridership which captured the effect of other modes of travel, likely walking and cycling. The Toronto Transit Commission (TTC) offers a competing rapid transit service within the boundaries of Toronto that has a longer travel time to Union station but can be accessed for a lower fare than GO Transit. A variable capturing which GO Rail stations face this competition was therefore developed to be used in the explanatory model. 


\subsection{Data Sources}

Information to complete this analysis was collected from GO Transit, Statistics Canada, and the Transportation Tomorrow Survey (TTS). Data was collected in spatial form, such as boundary shapefiles, and tabular form for demographic and ridership counts. GO Rail link and station shapefiles were obtained from the Government of Ontario's land information metadata website. A shapefile of TTC subway lines and stations was obtained through the Ryerson University Library Geospatial Map and Data Centre.

Ridership information was obtained from cordon count information generously provided by Metrolinx for use in this analysis. These counts took into account the number of passengers per train boarding and existing rail coaches at each station and also contained the number of seats available on each train consist. Cordon counts were taken during spring and fall of 2010, 2011, 2012, 2013, and 2015. The Fall 2014 count was completed as usual however the Spring 2014 count was replaced by a summer count. This summer count was excluded based on anomalous ridership information at several stations. The dates selected for cordon counts were carefully chosen to avoid major sporting or cultural events that would impact system ridership (Metrolinx, 2016). Ridership data was collected from rail trips between the 6:30 and 9:30 A.M. peak period defined by Metrolinx.

Census information and boundary files were drawn from the 2006 Census of Canada. Dissemination area (DA) level data was used in the analysis to provide a more fine-grained description of the areas in close proximity to GO Rail stations. The 2006 Census was considered more reliable than the 2011 National Household survey due to much lower non-response rates, particularly when evaluating factors at a small geographic scale such as dissemination areas.

Travel and trip data was obtained from the 2011 Transportation Tomorrow Survey (TTS) that includes information on trips such as origin, destination, mode, travel time as well as characteristics of the trip maker. The TTS was also used as a source for traffic analysis zone (TAZ) boundary files. 


\subsection{Methods}

To address the questions of which conditions create the most favourable environments for increasing ridership and utilization of capacity in response to service increases, four regression models were developed that evaluated cross-sectional and year-over-year changes in station-level ridership. The outcomes and descriptive statistics for each of these these models is presented in the following results chapter.

\subsection{Independent Variables}

Following the review of academic literature that produced a series of 12 factors expected to influence transit ridership, data was then collected from the 2006 census, Transportation Tomorrow Survey (TTS), and Metrolinx to be imported into Microsoft Excel so that each TAZ and DA had accompanying values for each of the identified factors. Table 2 shows the factor, name of the variable, and the predicted sign of the coefficient that describes whether the factor is positively or negatively associated to the dependent variable based on previous studies.

Table 2: Variables Included in the Regression Models Including Predicted Coefficient Signs and Variable Names

\begin{tabular}{|l|c|l|}
\hline \multicolumn{1}{|c|}{ Independent Variables } & Expected Sign & \multicolumn{1}{c|}{ Variable Name } \\
\hline Percent Immigrant & + & PERCENTIMMIGRANT \\
\hline Employment Rate & + & EMPLOY_RTE \\
\hline Median Income & + & MED_INC \\
\hline Population Density & + & POP_DENS \\
\hline Household Density & + & HH_DENS \\
\hline Percent of workers with free parking & - & FREEPARK \\
\hline Workers per Household & + & WORKERS.HH \\
\hline Percent 0 Car Households & - & X0CAR \\
\hline Percent 1 Car Households & - & X1CAR \\
\hline Percent 2+ Car Households & + & X2CAR \\
\hline Parking Capacity of Station & + & Parking Capacity \\
\hline Terminal Station & + & Terminal \\
\hline TTC Option & - & TTC_Option \\
\hline $\begin{array}{l}\text { All seasonal, line, and station fixed } \\
\text { effects }\end{array}$ & + & \\
\hline
\end{tabular}


Rail corridors and stations that form the GO Network were selected from the Government of Ontario's rail ownership shapefiles to create a GIS layer of GO station points and corridor lines in ArcGIS. Point and line features representing TTC rapid transit lines and stations acquired from the Ryerson University Geospatial Map \& Data Centre was also imported into ArcGIS.

In order to select dissemination areas and traffic analysis zones (TAZ) to be used in the analysis of station areas, shapefiles representing TAZs and DAs were added to ArcGIS and converted to point features. The name of the closest GO Rail Station to each point was added as an attribute field to the DAs and TAZs. A buffer of 1600m (1 mile) was created around each GO Rail station and representative TAZ and DA points were selected if they fell within this created buffer. This distance was chosen as the minimum distance that residential land uses would be present for all stations across the network as many exist in industrial or large format retail areas. If the point fell within the buffer, then it could be reasonably assumed that at least half of that TAZ or DA would be within the buffer area and impact the nearby station's ridership.

The list of selected DAs and TAZs was exported into Excel where it was used to eliminate areas beyond the $1600 \mathrm{~m}$ buffer from consideration of the regression model. The remaining list of factors was combined, using weighted averages based on population of each TAZ or DA, to build a profile of each station made up of the Census and TTS data. Vehicle ownership was categorized into proportion of 0 car households, proportion of 1 car households, proportion of households with 2 or more cars in order to test significance of different categories rather than an average vehicle ownership value for each station area.

A dummy variable was also added to each profile by assessing whether or not the station was a terminal station during the year that the cordon count was completed ("0"=no, " 1 "=yes). In order to create a dummy variable for if the station could be competing for riders with TTC rapid transit, a 4000m buffer was created in ArcGIS around TTC stations that was used to select GO Rail stations that fell within this distance of TTC subway stations. This selection produced a list of GO stations that had competing local transit service to downtown Toronto (" 0 "=no, "1"=yes) that was added to the station profile.

Parking capacity for each station profile was acquired from the GO Transit website. The measure for service frequency was obtained from the cordon count data provided by Metrolinx that detailed the number of seats of each train that stopped at each station. This was done manually as the use of express trains that do not stop at all stations on a particular corridor was 
not consistent across cordon count days. This produced a value for inbound seats offered for every station on the GO Rail network during the AM peak to be used a proxy measure for service frequency.

\subsection{Dependent Variables}

Values of ridership and utilization, a ratio of the ridership to the number of inbound seats offered, were calculated for each station on every cordon count day to be used as dependent variables using the following equation:

$$
\text { Utilization }=\frac{\text { Boardings }_{t}}{\text { Seats } \text { Offered }_{t}}
$$

The cross-sectional ridership dependent variable was by obtained through a calculation of the average ridership at each station over the time period from Spring of 2010 to Spring of 2015. Similarly, the cross-sectional utilization dependent variable was calculated for the same time period at each station. Utilization at each station for each cordon count year was also calculated to be used a dependent variable of capacity utilization for a given year. Another dependent variable, utilization growth, that shows year-over-year growth in utilization between cordon count days, was calculated using the following equation:

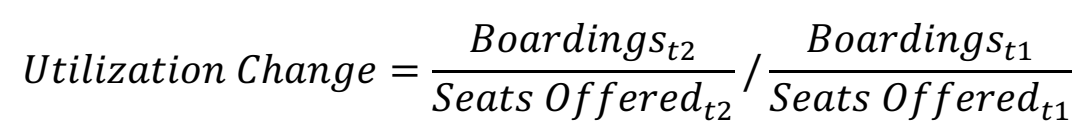

The rates of utilization change were calculated for every cordon count time period beginning with Spring 2010-Fall 2010 up to and including Fall 2014-Spring 2015. To account for the anomalous Summer 2014 count, the value for the rate of utilization change from the time period between Fall 2013 and Fall 2014 was squared in order to avoid a large increase/drop in the summer 2014 count. Squaring the term adjusted the value to be a compound of the two sixmonth periods rather than a yearly growth rate to match the other observations. This produced long-form panel data of dependent variables, rates of utilization change, and a set of independent 
variables made up of continuous and dummy variables, for each station to be used in a regression analysis.

In order to accurately examine the station areas and their associated factors several stations had to be excluded from the regression analysis. Union Station was eliminated as it serves as the terminus of all GO Rail lines and is the focal point of the network where the overwhelming majority of AM peak trips are destined. This project seeks to understand what factors contribute to utilization and ridership on trips that terminate at Union Station and evaluating the surrounding area of egress points and the impact on transit demand would be the focus for another study.

Several other stations were not included in the final model as they were added to the network during the period from 2010-2015 and were not present in all cordon counts. These stations where rail service was expanded during this time period were Kitchener, Guelph, Acton (Kitchener Corridor) and Allandale Waterfront (Barrie Corridor). The data for the Hamilton GO station (Lakeshore West Corridor) was also eliminated due to the relatively small number of train trips that service this station directly and also the presence of a competing express bus service to downtown Toronto offered by GO Transit.

Values were calculated for system-wide ridership, utilization, and AM capacity for each cordon count year to demonstrate the broad overall trends in boardings on the GO Rail network. Additionally, broad trends in all-day ridership was presented for the Lakeshore East and West corridors to explore trends in all-day ridership and capacity.

Regression models were estimated using ordinary least squares (OLS) regression calculations in the R statistical package. Four models were estimated to identify factors that affect transit ridership using different dependent variables. Model 1 evaluated the association between demographic and built form station area factors on cross-sectional ridership defined as the average ridership at a station over the time period from Spring of 2010 to Spring of 2015. Model 2 evaluated the correlation of the selected independent variables on cross-sectional utilization at each station. The results of these models are exploratory in nature due to a small number of observations $(\mathrm{N}=56)$ that can be used to inform decisions by policymakers about what land use decisions would benefit ridership and utilization.

Model 3 was constructed using the utilization rate at each station for each cordon count day as a dependent variable where biannual observations that were pooled for 2010 to 2015 . The 
model included the demographic and built form independent variables as well as fixed effect dummy variables for each station and each cordon count day as these factors would influence the calculated utilization rates and violate independence of error assumptions.

Model 4 evaluated the effect of independent variables on year-over-year utilization growth rates for each station between each time period. Independent variables used in this model were the demographic and built form factors for each station, a dummy variable to account for fixed effects from seasonality (cordon count days), and a dummy variable representing the corridor the station was located on ( 1 for being located on a particular corridor, 0 for not being located on a particular corridor).

The model building process was iterative and all models were run with combinations of natural logged dependent variables and natural logged independent variables to identify the most successful exploratory models based on the resultant $r^{2}$ coefficients and residual error plots that are presented in the following results chapter. Through all iterations, population density was producing anomalous coefficients and was competing with the household density variable. Population density was therefore dropped form the modelling process to produce clearer and more interpretable results. Models 3 and 4 also used a weighting factor based on the mean station ridership at each station in a given year to avoid the effect of large utilization rate/growth rate changes at stations with comparatively small actual ridership numbers. Model 4 also used a subset of utilization growth rates below four percent to eliminate outliers in the model.

Table 3: Model Summary

\begin{tabular}{|l|c|c|c|}
\hline & Dependent Variable & Independent Variables & $\begin{array}{l}\text { Number of observations } \\
\text { (N) }\end{array}$ \\
\hline $\begin{array}{l}\text { Model } \\
\mathbf{1}\end{array}$ & $\begin{array}{c}\text { Average ridership at each } \\
\text { station from Spring 2010- } \\
\text { Spring 2015 }\end{array}$ & $\begin{array}{c}\text { Built form and demographic } \\
\text { variables }\end{array}$ & 56 \\
$\mathbf{2}$ & $\begin{array}{c}\text { Average utilization at } \\
\text { each station from Spring } \\
\text { 2010-Spring 2015 }\end{array}$ & $\begin{array}{c}\text { Built form and demographic } \\
\text { variables }\end{array}$ & 56 \\
\hline $\begin{array}{l}\text { Model } \\
\text { Model }\end{array}$ & $\begin{array}{c}\text { Utilization Rate at each } \\
\text { station and each cordon } \\
\text { count day }\end{array}$ & $\begin{array}{c}\text { Built form and demographic } \\
\text { variables, seasonal fixed effects, } \\
\text { station fixed effects }\end{array}$ & 504 \\
$\mathbf{4}$ & $\begin{array}{c}\text { between each cordon } \\
\text { count day at each station }\end{array}$ & $\begin{array}{c}\text { Built form and demographic } \\
\text { variables, seasonal fixed effects, } \\
\text { corridor fixed effects }\end{array}$ & 504 \\
\hline
\end{tabular}




\section{$\underline{6.0 \text { Results }}$}

The broad trends of GO Rail AM boardings, utilization, and capacity were calculated to provide context for the regression analysis of cross-sectional and year-over-year station-level dependent variables. This context is important to account for in regression models to more accurately understand the impact of factors on station boardings having considered overall ridership growth on the network and on specific corridors. All-day ridership and capacity were also calculated for Lakeshore East and Lakeshore West in order to explore the behavioural response of riders to increases in all-day service and demonstrate the trend in ridership growth that can be initiated through new off-peak capacity.

Figure 3: Growth in Boardings at GO Rail stations excluding Union Station

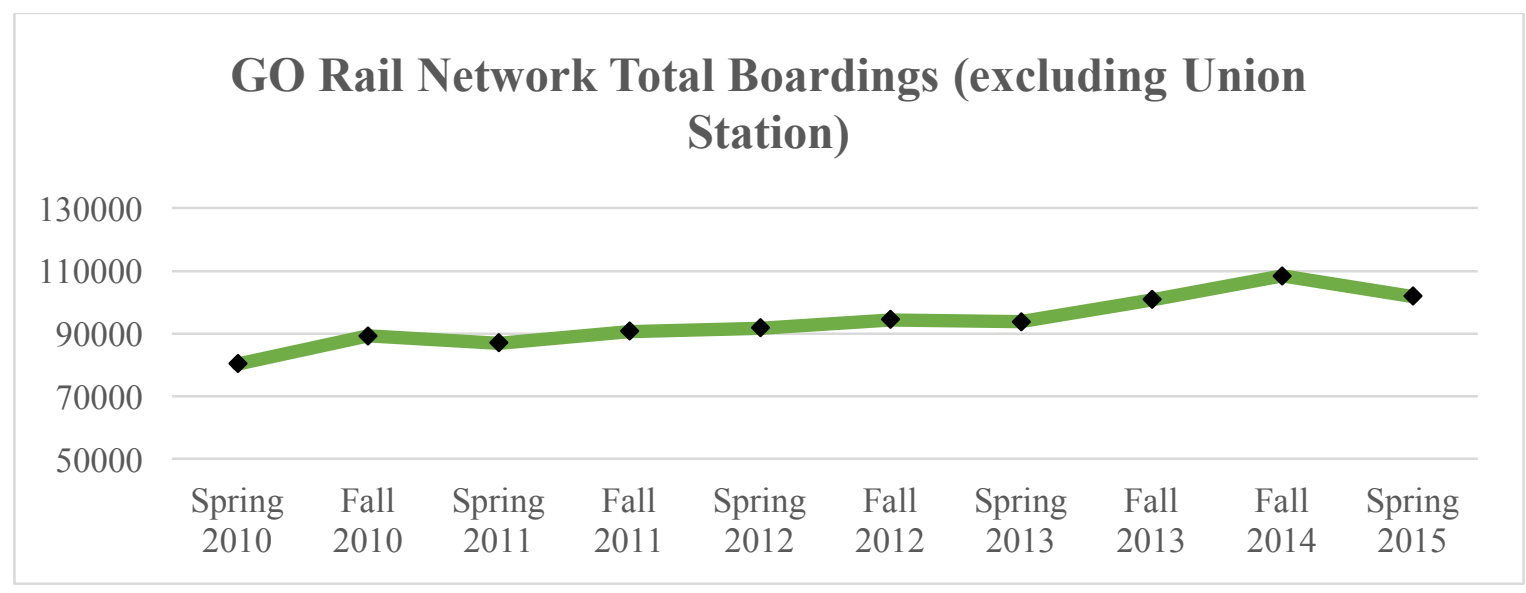

The overall change in ridership has grown from 80000 to over 100000 riders in the AM peak period between Spring of 2010 and Spring of 2015. This trend was accounted for in the regression models by either looking at cross-sectional dependent variables or by including fixed seasonal effects in the list of independent variables. The growth in AM utilization in Figure 4 shows large swings from year to year but generally is trending upward with a utilization around $17 \%$. These numbers for each station were weighted to avoid large rate changes at low ridership stations.

The system-wide utilization points to broad trends in overall riders based on inbound seats offered but differences among station and line utilization are explained by the more detailed statistical regression models. 


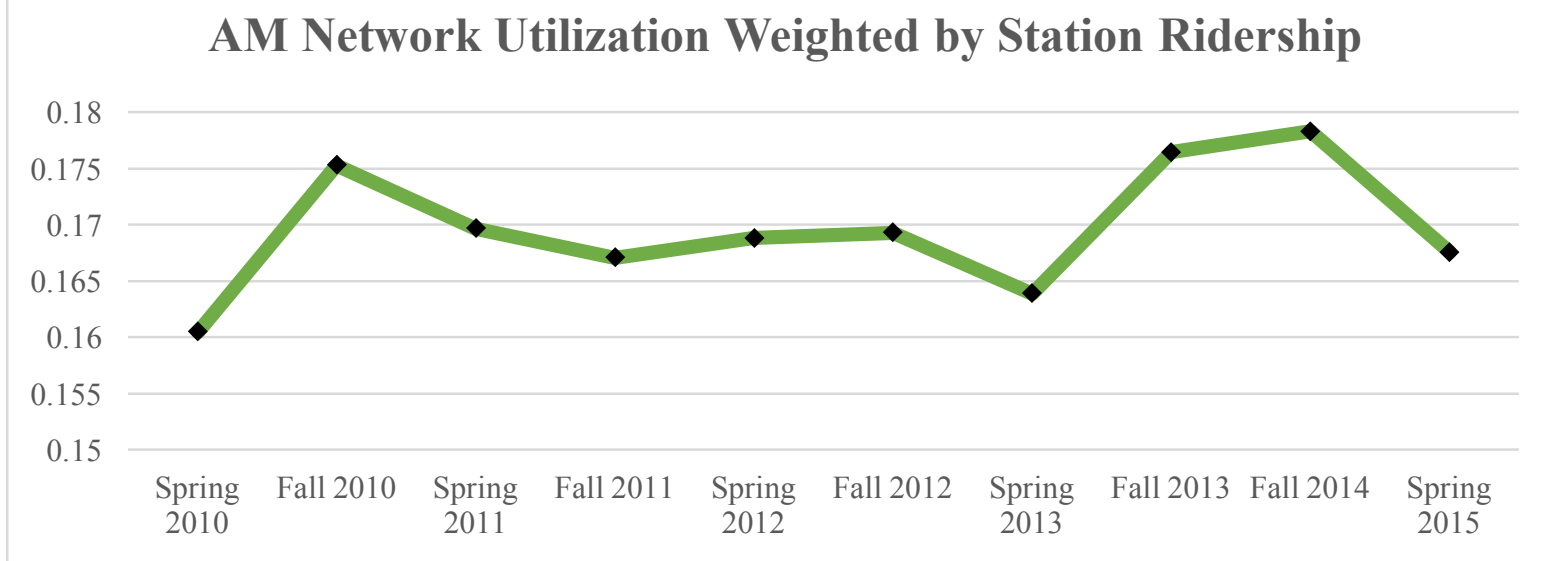

The changes in utilization appear pronounced but are numerically small given the scale of the chart. Network utilization has been near $17 \%$ for the time period defined in this research. System capacity also steadily increased from Spring 2010 to Spring 2015 in Figure 5 and also sharply rose in the Fall of 2014 which may have contributed to the drop in average utilization.

Figure 5: Seats Offered on GO Rail in the AM Peak

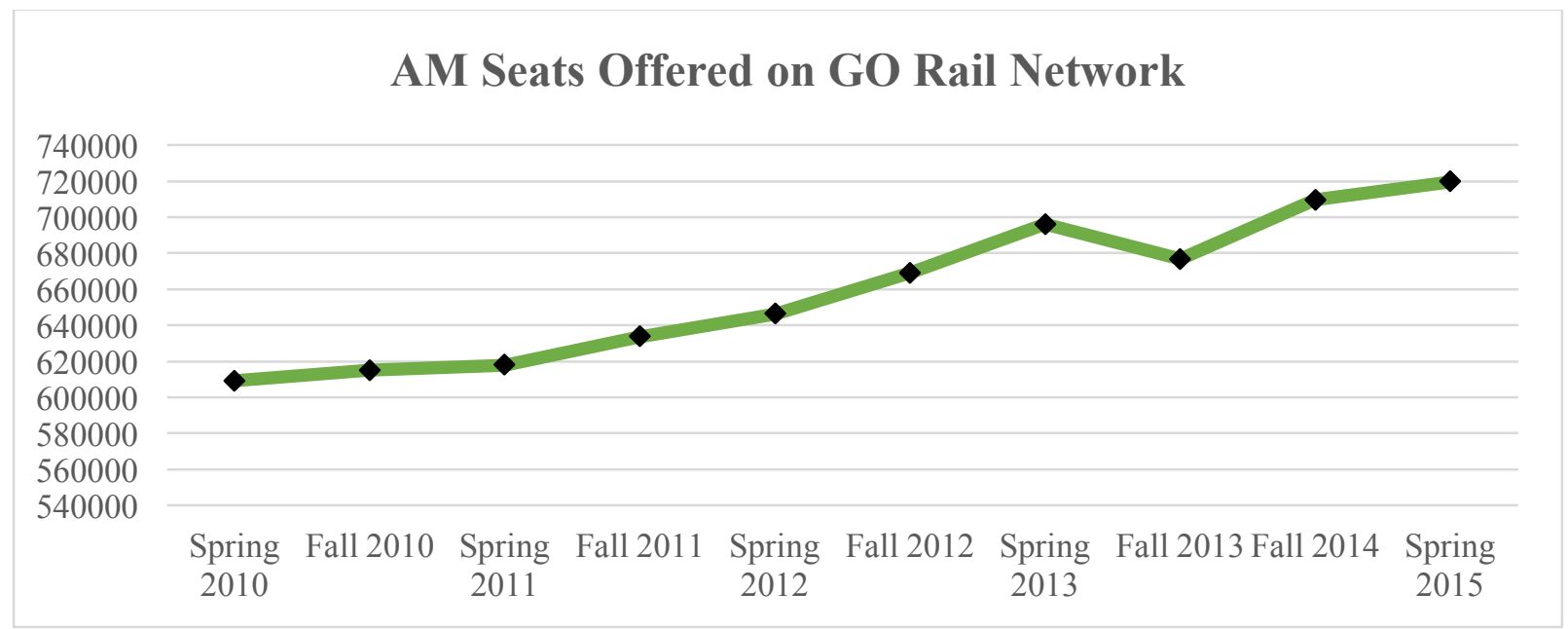

These increases and changes in capacity from one year to the next are the result of the purchase and phasing in of new rail coaches that had fewer seats and demanded an increase in number of coaches per train that resulted in a net increase of capacity. Figure 6 shows the breakdown of AM ridership by rail corridor for each cordon count day and the importance of the 
Lakeshore East and West lines to the total number of AM boardings while also showing the fiveyear trend in ridership per line.

Figure 6: AM Peak Boardings on GO Rail Corridors

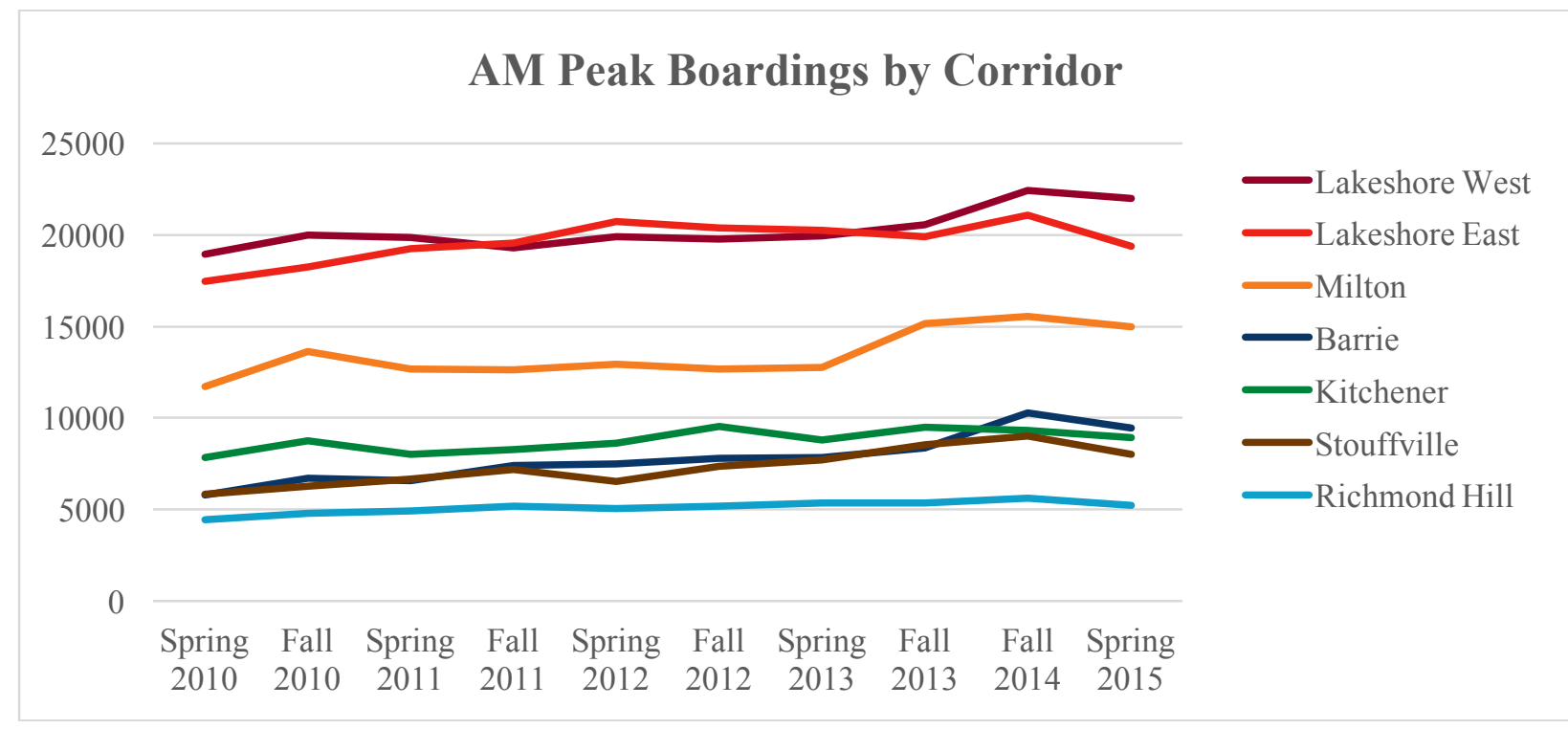

This chart shows the ridership trends by corridor and shows the overall growth in ridership as well as the effect of the high ridership numbers collected in the Fall 2014 count. Lakeshore East and West were further examined for their all-day ridership (Figure 7) and the capacity increases that took place in 2013 (Figure 8).

Figure 7: Lakeshore East and West All-Day Boardings

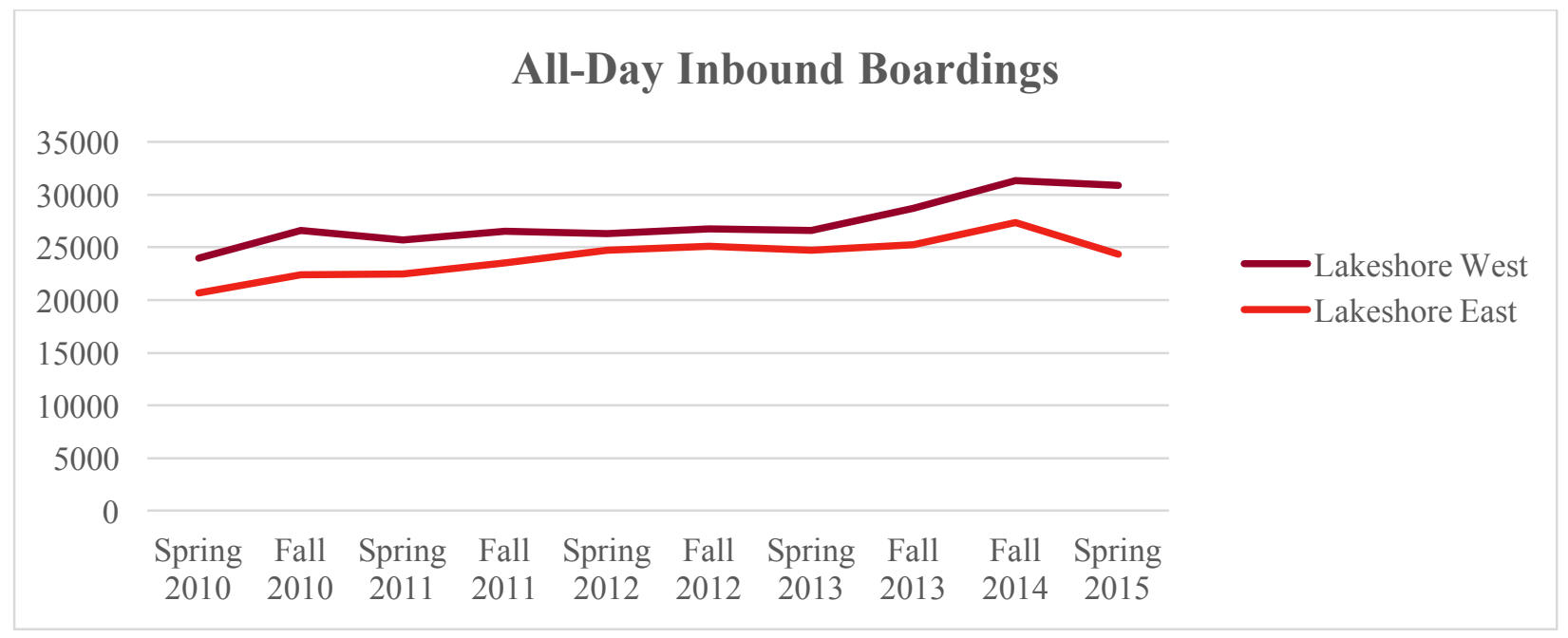




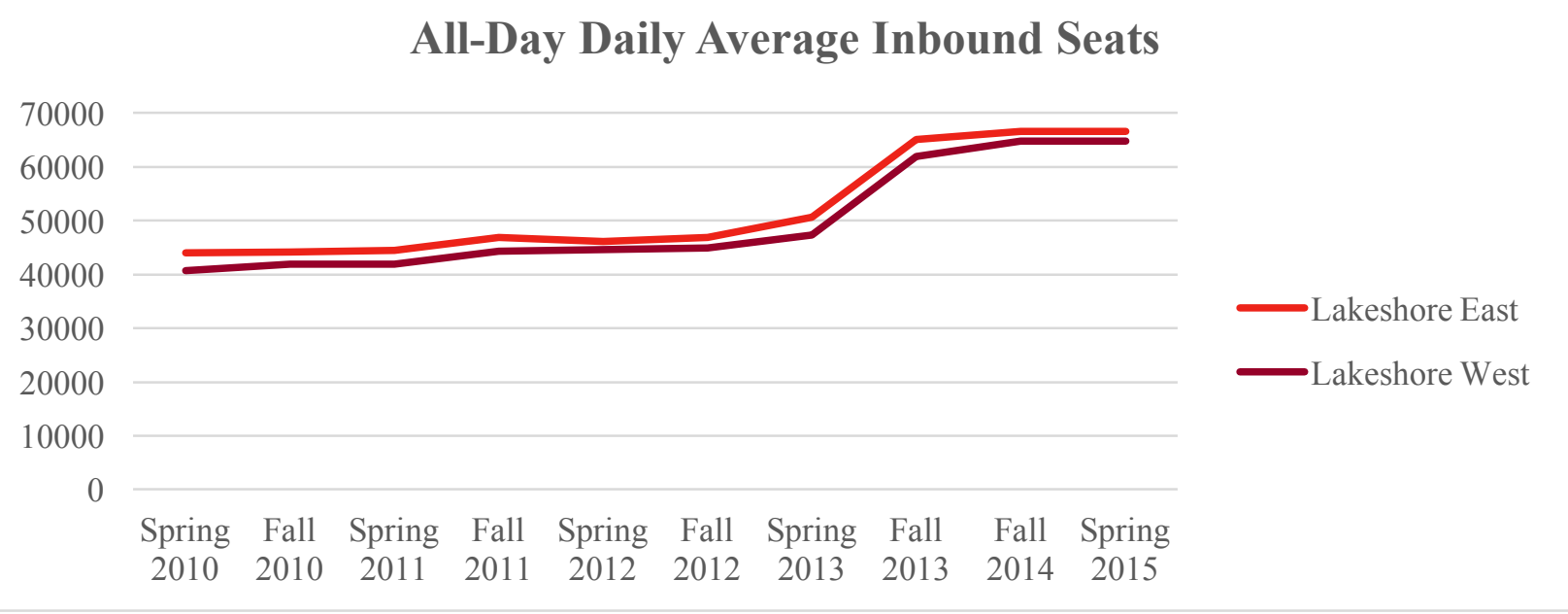

The Lakeshore East and Lakeshore West corridors were the only corridors to experience an increase in all-day capacity during the study period. These two charts show the initial years of a service increase and the effects that more all-day capacity can have on ridership. Due to the dramatic increase in service capacity and the slow change in behaviour and ridership it can be expected that utilization rates would be initially lower after an all-day service increase.

The charts show the service increase did contribute to an all day ridership boost on both lines but AM ridership still accounts for a large majority of inbound trips on these two lines. Also, Lakeshore West is utilized more during the off-peak hours than Lakeshore East despite fewer seats offered meaning there are factors that make it more conducive to generating all-day ridership. While the exploration of factors affecting all-day ridership was beyond the scope of this research it will be important to monitor capacity utilization on two-way, all-day service as it rolls out on other corridors to evaluate the best strategies for generating all-day ridership. This research provides a framework for evaluating these factors based on station level ridership and capacity that provide recommendations on flexible service changes to maximize ridership.

\section{1: Model 1}

Model 1 evaluated factors impacting cross-sectional or average ridership over the time period examined and produced a set of significant independent variables (Table 4). The model that performed best was run with a natural logged average ridership dependent variable (Figure 9). 
Table 4: Output of Average Ridership Model (Model 1)

$\begin{array}{ccccc}\text { Min } & 1 \mathrm{Q} & \text { Median } & \text { 3Q } & \text { Max } \\ -1.23632 & -0.26499 & 0.01287 & 0.33115 & 0.93618\end{array}$

\begin{tabular}{|c|c|c|c|c|l|}
\hline Coefficients & Estimate & Std. & Error & t value & Pr( $(>|\mathbf{t}|)$ \\
\hline (Intercept) & $3.47 \mathrm{E}+00$ & $2.03 \mathrm{E}+00$ & 1.707 & 0.094915 &. \\
\hline PERCIMMIGRANT & $2.35 \mathrm{E}-03$ & $9.20 \mathrm{E}-03$ & 0.255 & 0.799784 & \\
\hline EMPLOY_RTE & $-2.72 \mathrm{E}-02$ & $2.16 \mathrm{E}-02$ & -1.256 & 0.215695 & \\
\hline MED_INC & $1.99 \mathrm{E}-05$ & $2.98 \mathrm{E}-05$ & 0.667 & 0.508165 & \\
\hline HH_DENS & $7.69 \mathrm{E}-05$ & $1.74 \mathrm{E}-04$ & 0.443 & 0.660268 & \\
\hline FREEPARK & $2.42 \mathrm{E}-02$ & $1.12 \mathrm{E}-02$ & 2.154 & 0.036716 & $*$ \\
\hline WORKERS.HH & $1.28 \mathrm{E}+00$ & $3.60 \mathrm{E}-01$ & 3.555 & 0.000917 & $* * *$ \\
\hline X0CAR & $-3.55 \mathrm{E}-02$ & $2.53 \mathrm{E}-02$ & -1.403 & 0.167737 & \\
\hline X1CAR & $1.47 \mathrm{E}-02$ & $8.79 \mathrm{E}-03$ & 1.668 & 0.102429 & \\
\hline X2CAR & NA & NA & NA & NA & \\
\hline ParkingCapacity & $5.60 \mathrm{E}-04$ & $8.73 \mathrm{E}-05$ & 6.411 & $8.40 \mathrm{E}-08$ & $* * *$ \\
\hline TTC_Option & $-3.45 \mathrm{E}-01$ & $3.48 \mathrm{E}-01$ & -0.99 & 0.3275 & \\
\hline Terminal & $-4.53 \mathrm{E}-01$ & $2.54 \mathrm{E}-01$ & -1.784 & 0.081311 &. \\
\hline
\end{tabular}

Signif. codes: 0 '***' 0.001 '**' 0.01 '*' 0.05 '? 0.1 ' ' 1

Residual standard error: 0.5519 on 44 degrees of freedom

Multiple R-squared: $0.7862 \quad$ Adjusted R-squared: 0.7327

F-statistic: 14.71 on 11 and 44 DF, p-value: $2.308 \mathrm{e}-11$

Figure 9: Residual Plot of Average Ridership Model (Model 1)

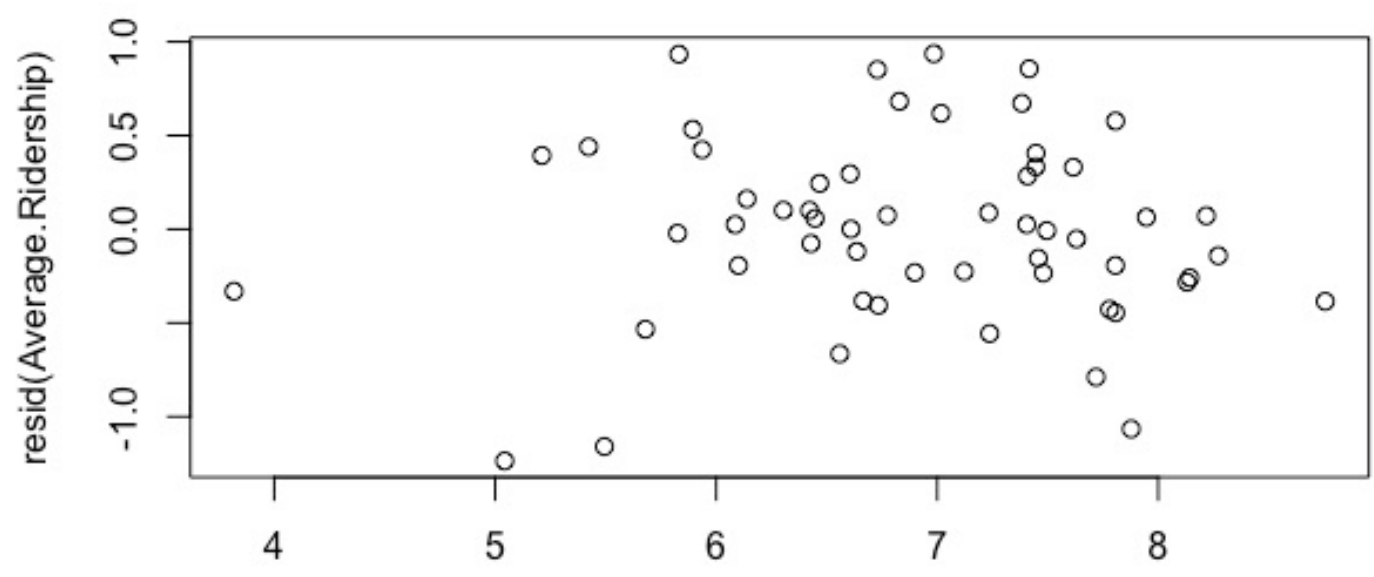

fitted(Average.Ridership) 
The most significant factors were found to be parking capacity, workers per household, terminal stations, and percentage of workers with free parking. The model fit was high, demonstrated by a high $\mathrm{r}^{2}$ value showing the extreme significance of the parking capacity variable and workers per household. The coefficient of the free parking at work variable was the opposite of what was expected and thus ridership may be driven more by station parking availability, the aversion to automobile traffic congestion on the routes leading to downtown Toronto, or that people in areas surrounding GO station may be employed in areas with free parking and not in downtown Toronto.

Interestingly, a terminal station actually exhibited lower ridership despite a theoretically larger catchment area than an inline station. This may be a result of fewer train trips that serve these terminals as express trains serve high-ridership in-line stations. Terminals may also be located in smaller centres or industrial areas that do not attract a large number of riders from the surrounding area compared to more populated areas along the corridor. Any ridership increases from a larger catchment area at these terminal stations could be attributed to greater parking supply that would be captured in the separate parking capacity variable.

The strong effect of workers per household was a result of the commuter-driven AM ridership of GO Rail that brings workers to the largest employment centre in the region, downtown Toronto. The effect of parking capacity on average station ridership demonstrates the context of most stations that draw riders from auto-dependent environments that are difficult to access by active transportation or local transit. The high $\mathrm{r}^{2}$ value and evenly distributed residual plot show the strong effect of these two variables in explaining cross-sectional ridership.

The small number of observations used in this model limits the general applicability of the results but exploratory research and modeling on significant factors that impact broad trends and cross-sectional changes is necessary to build an understanding control factors used in more predictive models.

\section{2: Model 2}

Model 2 carried out a similar cross-sectional analysis of utilization at each station and produced similar results to the cross-sectional ridership model. Parking capacity was extremely significant to cross-sectional station utilization and again demonstrated the value of park and ride provision to AM commuter rail utilization. The strongest iteration of this model was run with 
without natural logged dependent and independent variables to produce a model with the highest $r^{2}$ value (Table 5) and favourable residual distribution (Figure 10).

Table 5: Output of Average Utilization Model (Model 2)

$\begin{array}{ccccc}\text { Min } & \text { 1Q } & \text { Median } & \text { 3Q } & \text { Max } \\ -0.102791 & -0.032902 & -0.000895 & 0.021018 & 0.19523\end{array}$

\begin{tabular}{|l|c|l|l|c|l|}
\hline Coefficients & Estimate & Std. & Error & t value & $\operatorname{Pr}(>|\mathbf{t}|)$ \\
\hline Intercept) & $-2.71 \mathrm{E}-01$ & $2.16 \mathrm{E}-01$ & -1.254 & 0.216 & \\
\hline PERCIMMIGRANT & $9.91 \mathrm{E}-04$ & $9.78 \mathrm{E}-04$ & 1.014 & 0.316 & \\
\hline EMPLOY_RTE & $2.68 \mathrm{E}-03$ & $2.30 \mathrm{E}-03$ & 1.165 & 0.25 & \\
\hline MED_INC & $-1.11 \mathrm{E}-06$ & $3.17 \mathrm{E}-06$ & -0.351 & 0.728 & \\
\hline HH_DENS & $1.47 \mathrm{E}-05$ & $1.84 \mathrm{E}-05$ & 0.799 & 0.429 & \\
\hline FREEPARK & $1.40 \mathrm{E}-03$ & $1.19 \mathrm{E}-03$ & 1.173 & 0.247 & \\
\hline WORKERS.HH & $2.65 \mathrm{E}-02$ & $3.82 \mathrm{E}-02$ & 0.694 & 0.491 & \\
\hline X0CAR & $-1.63 \mathrm{E}-03$ & $2.69 \mathrm{E}-03$ & -0.606 & 0.548 & \\
\hline X1CAR & $4.95 \mathrm{E}-04$ & $9.33 \mathrm{E}-04$ & 0.531 & 0.598 & \\
\hline X2CAR & NA & NA & NA & NA & \\
\hline ParkingCapacity & $4.10 \mathrm{E}-05$ & $9.27 \mathrm{E}-06$ & 4.426 & $6.24 \mathrm{E}-05$ & $* * *$ \\
\hline TTC_Option & $-2.86 \mathrm{E}-02$ & $3.70 \mathrm{E}-02$ & -0.774 & 0.443 & \\
\hline Terminal & $-2.09 \mathrm{E}-03$ & $2.70 \mathrm{E}-02$ & -0.077 & 0.939 & \\
\hline Sigif. cods: & 0.001 & & \\
\hline
\end{tabular}

Signif. codes: 0 ‘***’ 0.001 '**’ 0.01 '*’ 0.05 ', 0.1 ' ’ 1

Residual standard error: 0.05861 on 44 degrees of freedom

Multiple R-squared: $0.5477, \quad$ Adjusted R-squared: 0.4346

F-statistic: 4.843 on 11 and 44 DF, p-value: $7.34 \mathrm{e}-05$ 
Figure 10: Residual Plot of Average Utilization Model (Model 2)

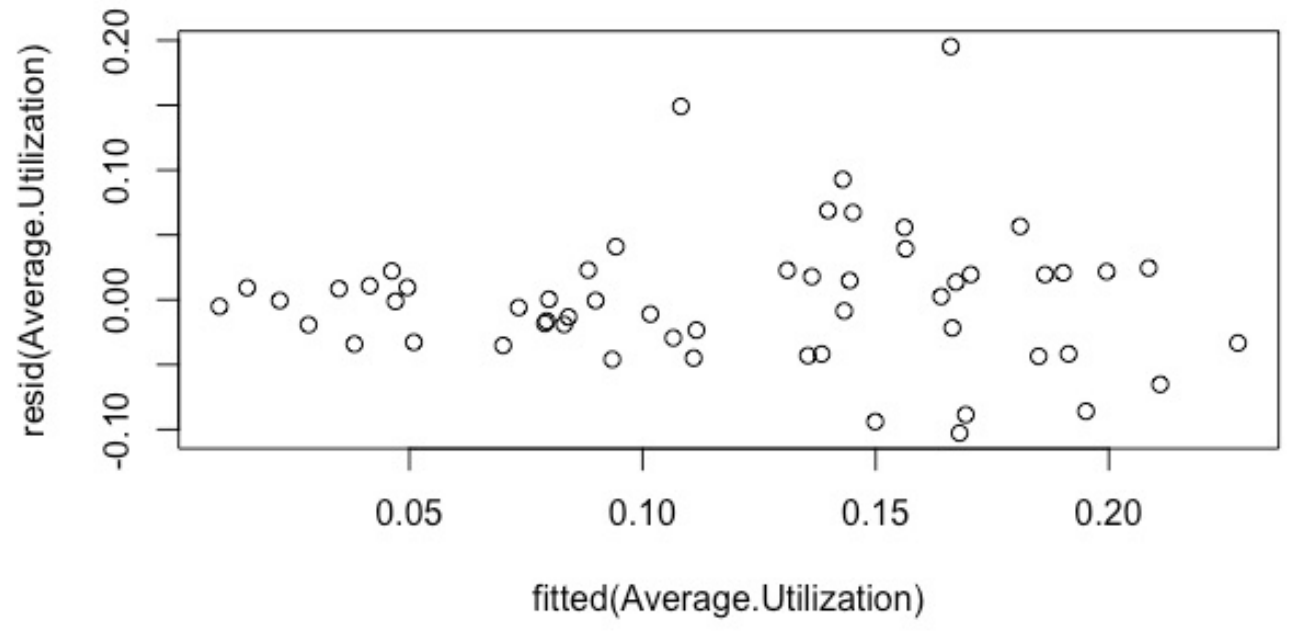

Due to the strong connection between utilization and parking it is reasonable to conclude that building increased parking capacity would increase ridership and would better utilize current capacity of GO Rail services. This is further supported by the positive coefficient associated proportion of two or more car households and negative coefficient associated with proportion of zero car households showing riders with cars are accessing GO Rail services and utilization would increase after providing more station parking. Most other studies found the opposite relationship between these factors and transit ridership but in more auto-oriented environments for commuter rail, parking access appears to drive utilization.

From a policy perspective however, the results of model 1 and 2 present potentially competing findings highlight a tension between the findings in from these models and recent land use policy directions. Model 1 and 2 demonstrate that developing parking capacity may provide a more immediate catalyst to ridership but may also encourage riders to live in autodependent locations and access stations by car. This would result in more station access by automobile and is also in direct opposition to the pursuit of compact, walkable, vibrant, and transit-supportive built environments that are the focus of current plans and policies such as the Growth Plan and The Big Move. Also, there are limits to the amount of parking that can be constructed to generate new ridership. Physical constraints and road access around station areas may also present challenges to parking expansion by causing bottlenecks at AM and PM peak periods requiring road infrastructure that is only used at certain points of the day. There will also 
be a point when parking expansion begins to deliver lower incremental benefits due to distance required to walk from parking spaces to a station or traffic congestion.

These findings also highlight the caution required when making long term policy decisions based solely on historical data and the need for policy and land use interventions to encourage access by other modes. Encouraging station access by other modes such as active transportation that have fewer environmental impacts than automobiles can also support residential and commercial intensification to create nodes of development and activity around stations. Parking may also be useful in generating AM boardings on commuter rail services but does little to entice to riders exit there from other locations. This will be a key discussion when two-way, all-day service rolls out beyond the peak commuter periods and areas around stations will begin to evolve into all-day destinations for employment, residential, or other uses.

\section{3: Model 3}

Model 3 showed factors affecting year-over-year station-level utilization or the impact of station area factors on the ratio of boardings to capacity offered. The iteration of this model that performed best used dependent and independent variables that were not natural logged and also included fixed effects for seasonality and station. The results were also weighted by station ridership to avoid the overrepresentation of small numeric ridership changes at stations affecting utilization rates. The demographic and built factors that were found to be significant to utilization were income, percent of recent immigrants, employment rate, proportion of zero car households, proportion of 1 car households, workers per household, and terminal station effects (Table 6, Figure 11). The fixed station effects were also significant to utilization and provided a look at where capacity was being utilized.

Table 6: Output of Station-level Utilization Rate Model (Model 3)

$\begin{array}{ccccc}\text { Min } & \text { 1Q } & \text { Median } & \text { 3Q } & \text { Max } \\ -0.064301 & -0.006419 & 0.000286 & 0.006387 & 0.097245\end{array}$

\begin{tabular}{|l|l|l|c|c|l|}
\hline Coefficients & Estimate & Std. & Error & t value & $\operatorname{Pr}(>|\mathbf{t}|)$ \\
\hline (Intercept) & $-6.50 \mathrm{E}+00$ & $2.13 \mathrm{E}+00$ & -3.053 & 0.002401 & $* *$ \\
\hline PERCIMMIGRANT & $2.89 \mathrm{E}-02$ & $9.67 \mathrm{E}-03$ & 2.99 & 0.002944 & $* *$ \\
\hline EMPLOY_RTE & $3.96 \mathrm{E}-02$ & $1.16 \mathrm{E}-02$ & 3.41 & 0.000709 & $* * *$ \\
\hline MED_INC & $3.76 \mathrm{E}-05$ & $1.26 \mathrm{E}-05$ & 2.989 & 0.002957 & $* *$ \\
\hline
\end{tabular}




\begin{tabular}{|c|c|c|c|c|c|}
\hline HH_DENS & $-1.60 \mathrm{E}-05$ & 4.24E-05 & -0.378 & 0.705865 & \\
\hline FREEPARK & $3.33 \mathrm{E}-02$ & $1.17 \mathrm{E}-02$ & 2.858 & 0.00446 & $* *$ \\
\hline WORKERS.HH & $-6.14 \mathrm{E}-01$ & $1.67 \mathrm{E}-01$ & -3.674 & 0.000268 & $* * *$ \\
\hline XOCAR & $2.41 \mathrm{E}-02$ & $7.73 \mathrm{E}-03$ & 3.121 & 0.001923 & $* *$ \\
\hline X1CAR & $-3.10 \mathrm{E}-03$ & 8.00E-04 & -3.88 & 0.00012 & $* * *$ \\
\hline X2CAR & NA & NA & NA & NA & \\
\hline ParkingCapacity & $-4.58 \mathrm{E}-05$ & 7.73E-05 & -0.592 & 0.55415 & \\
\hline TTC_Option & $1.69 \mathrm{E}-01$ & $8.65 \mathrm{E}-02$ & 1.95 & 0.051778 & \\
\hline Terminal & $2.18 \mathrm{E}-02$ & $8.52 \mathrm{E}-03$ & 2.562 & 0.010725 & $*$ \\
\hline Fall.2010 & $3.68 \mathrm{E}-03$ & $3.18 \mathrm{E}-03$ & 1.159 & 0.246962 & \\
\hline Spring.2011 & $2.24 \mathrm{E}-03$ & $3.18 \mathrm{E}-03$ & 0.707 & 0.480015 & \\
\hline Fall.2011 & $2.01 \mathrm{E}-03$ & $3.18 \mathrm{E}-03$ & 0.632 & 0.52744 & \\
\hline Spring.2012 & $1.20 \mathrm{E}-03$ & $3.16 \mathrm{E}-03$ & 0.38 & 0.703916 & \\
\hline Fall.2012 & $3.20 \mathrm{E}-03$ & $3.16 \mathrm{E}-03$ & 1.012 & 0.312124 & \\
\hline Spring.2013 & $-2.30 \mathrm{E}-03$ & $3.16 \mathrm{E}-03$ & -0.726 & 0.468215 & \\
\hline Fall.2013 & $7.55 \mathrm{E}-03$ & $3.16 \mathrm{E}-03$ & 2.389 & 0.01732 & $*$ \\
\hline Fall.2014 & $9.22 \mathrm{E}-03$ & $3.16 \mathrm{E}-03$ & 2.917 & 0.003712 & $* *$ \\
\hline Spring.2015 & NA & NA & NA & NA & \\
\hline Aldershot & 4.09E-01 & $3.16 \mathrm{E}-01$ & 1.292 & 0.196947 & \\
\hline Burlington & $3.08 \mathrm{E}-01$ & $1.86 \mathrm{E}-01$ & 1.652 & 0.099167 & . \\
\hline Appleby & $1.65 \mathrm{E}-01$ & $1.81 \mathrm{E}-01$ & 0.914 & 0.361361 & \\
\hline Bronte & $6.13 \mathrm{E}-01$ & $3.10 \mathrm{E}-01$ & 1.978 & 0.048502 & $*$ \\
\hline Oakville & $1.94 \mathrm{E}-01$ & $2.61 \mathrm{E}-01$ & 0.744 & 0.457078 & \\
\hline Clarkson & $4.83 \mathrm{E}-01$ & $2.94 \mathrm{E}-01$ & 1.644 & 0.100977 & \\
\hline Port.Credit & $-6.77 \mathrm{E}-02$ & $2.44 \mathrm{E}-02$ & -2.772 & 0.005804 & $* *$ \\
\hline Long.Branch & $3.87 \mathrm{E}-01$ & $1.29 \mathrm{E}-01$ & 2.991 & 0.002939 & $* *$ \\
\hline Mimico & $2.59 \mathrm{E}-01$ & $7.75 \mathrm{E}-02$ & 3.336 & 0.000921 & $* * *$ \\
\hline Oshawa & $1.88 \mathrm{E}+00$ & $6.89 \mathrm{E}-01$ & 2.728 & 0.006636 & $* *$ \\
\hline Whitby & $8.11 \mathrm{E}-01$ & $4.41 \mathrm{E}-01$ & 1.839 & 0.066624 & 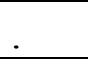 \\
\hline Ajax & $4.36 \mathrm{E}-01$ & $1.59 \mathrm{E}-01$ & 2.74 & 0.006399 & $* *$ \\
\hline Pickering & $4.65 \mathrm{E}-01$ & $3.33 \mathrm{E}-01$ & 1.397 & 0.163167 & \\
\hline Rouge.Hill & $2.09 \mathrm{E}-01$ & $1.10 \mathrm{E}-01$ & 1.899 & 0.058285 & . \\
\hline Guildwood & $1.65 \mathrm{E}-01$ & $2.10 \mathrm{E}-01$ & 0.787 & 0.431584 & \\
\hline Eglinton & $1.30 \mathrm{E}-01$ & $6.15 \mathrm{E}-02$ & 2.12 & 0.034535 & $*$ \\
\hline Scarborough & $5.91 \mathrm{E}-01$ & $2.11 \mathrm{E}-01$ & 2.8 & 0.005329 & $* *$ \\
\hline Danforth & $5.50 \mathrm{E}-01$ & $2.45 \mathrm{E}-01$ & 2.242 & 0.02543 & $*$ \\
\hline Georgetown & $7.26 \mathrm{E}-02$ & 3.94E-02 & 1.841 & 0.066304 & . \\
\hline Mount.Pleasant & $-2.39 \mathrm{E}-01$ & $6.95 \mathrm{E}-02$ & -3.437 & 0.000644 & $* * *$ \\
\hline Brampton & $-8.21 \mathrm{E}-02$ & 4.46E-02 & -1.84 & 0.066468 & \\
\hline
\end{tabular}




\begin{tabular}{|l|c|c|c|c|l|} 
Bramalea & $-2.49 \mathrm{E}-02$ & $3.12 \mathrm{E}-02$ & -0.798 & 0.425106 & \\
\hline Malton & $-2.76 \mathrm{E}-01$ & $1.14 \mathrm{E}-01$ & -2.43 & 0.015485 & $*$ \\
\hline Etobicoke.North & $1.35 \mathrm{E}-01$ & $6.99 \mathrm{E}-02$ & 1.924 & 0.055064 &. \\
\hline Weston & $-1.61 \mathrm{E}-02$ & $2.20 \mathrm{E}-02$ & -0.732 & 0.46461 & \\
\hline Bloor & $2.64 \mathrm{E}-01$ & $1.84 \mathrm{E}-01$ & 1.436 & 0.151782 & \\
\hline Richmond.Hill.1 & $3.49 \mathrm{E}-01$ & $1.49 \mathrm{E}-01$ & 2.352 & 0.019091 & $*$ \\
\hline Langstaff & $-2.36 \mathrm{E}-02$ & $5.64 \mathrm{E}-02$ & -0.418 & 0.67622 & \\
\hline Old.Cummer & $2.04 \mathrm{E}-01$ & $5.33 \mathrm{E}-02$ & 3.829 & 0.000147 & $* * *$ \\
\hline Oriole & $-1.69 \mathrm{E}-01$ & $7.92 \mathrm{E}-02$ & -2.134 & 0.033373 & $*$ \\
\hline Milton.1 & $-4.05 \mathrm{E}-01$ & $7.78 \mathrm{E}-02$ & -5.204 & $3.00 \mathrm{E}-07$ & $* * *$ \\
\hline Lisgar & $-5.72 \mathrm{E}-01$ & $1.64 \mathrm{E}-01$ & -3.493 & 0.000526 & $* * *$ \\
\hline Meadowvale & $-5.09 \mathrm{E}-01$ & $1.02 \mathrm{E}-01$ & -4.993 & $8.58 \mathrm{E}-07$ & $* * *$ \\
\hline Streetsville & $-1.96 \mathrm{E}-01$ & $3.12 \mathrm{E}-02$ & -6.295 & $7.48 \mathrm{E}-10$ & $* * *$ \\
\hline Erindale & $-1.40 \mathrm{E}-01$ & $2.47 \mathrm{E}-02$ & -5.681 & $2.45 \mathrm{E}-08$ & $* * *$ \\
\hline Cooksville & $-4.17 \mathrm{E}-01$ & $5.20 \mathrm{E}-02$ & -8.008 & $1.06 \mathrm{E}-14$ & $* * *$ \\
\hline Dixie & $-6.91 \mathrm{E}-02$ & $7.64 \mathrm{E}-03$ & -9.046 & $2.00 \mathrm{E}-16$ & $* * *$ \\
\hline Kipling & $-1.20 \mathrm{E}-01$ & $7.90 \mathrm{E}-02$ & -1.515 & 0.130496 & \\
\hline Lincolnville & $2.77 \mathrm{E}-01$ & $1.23 \mathrm{E}-01$ & 2.248 & 0.025065 & $*$ \\
\hline Stouffville.1 & $3.66 \mathrm{E}-01$ & $1.18 \mathrm{E}-01$ & 3.111 & 0.001987 & $* *$ \\
\hline Mount.Joy & $-7.68 \mathrm{E}-02$ & $1.86 \mathrm{E}-02$ & -4.127 & $4.40 \mathrm{E}-05$ & $* * *$ \\
\hline Markham & $5.84 \mathrm{E}-02$ & $1.71 \mathrm{E}-02$ & 3.422 & 0.000681 & $* * *$ \\
\hline Centennial & $-3.09 \mathrm{E}-01$ & $1.05 \mathrm{E}-01$ & -2.949 & 0.00336 & $* *$ \\
\hline Unionville & $1.34 \mathrm{E}-01$ & $3.42 \mathrm{E}-02$ & 3.921 & 0.000102 & $* * *$ \\
\hline Milliken & $1.19 \mathrm{E}-02$ & $1.58 \mathrm{E}-02$ & 0.753 & 0.451991 & \\
\hline Agincourt & NA & NA & NA & NA & \\
\hline Kennedy & NA & NA & NA & NA & \\
\hline Barrie.South & NA & NA & NA & NA & \\
\hline Bradford & NA & NA & NA & NA & \\
\hline East.Gwillimbury & NA & NA & NA & NA & \\
\hline Newmarket & NA & NA & NA & NA & \\
\hline Aurora & NA & NA & NA & NA & \\
\hline King.City & NA & NA & NA & NA & \\
\hline Rutherford & NA & NA & NA & NA & \\
\hline Maple & NA & NA & NA & NA & \\
\hline York.University & NA & NA & NA & NA & \\
\hline Sigif. cods: & 0.001 & & \\
\hline
\end{tabular}

Signif. codes: 0 '***’ 0.001 '**' 0.01 '*’ 0.05 ', $0.1^{\prime}$ ' 1

Residual standard error: 0.01672 on 439 degrees of freedom

Multiple R-squared: 0.9615, Adjusted R-squared: 0.9559

F-statistic: 171.5 on 64 and 439 DF, p-value: $<2.2 \mathrm{e}-16$ 
Figure 11: Residual Plot of Station-level Utilization Rate Model (Model 3)

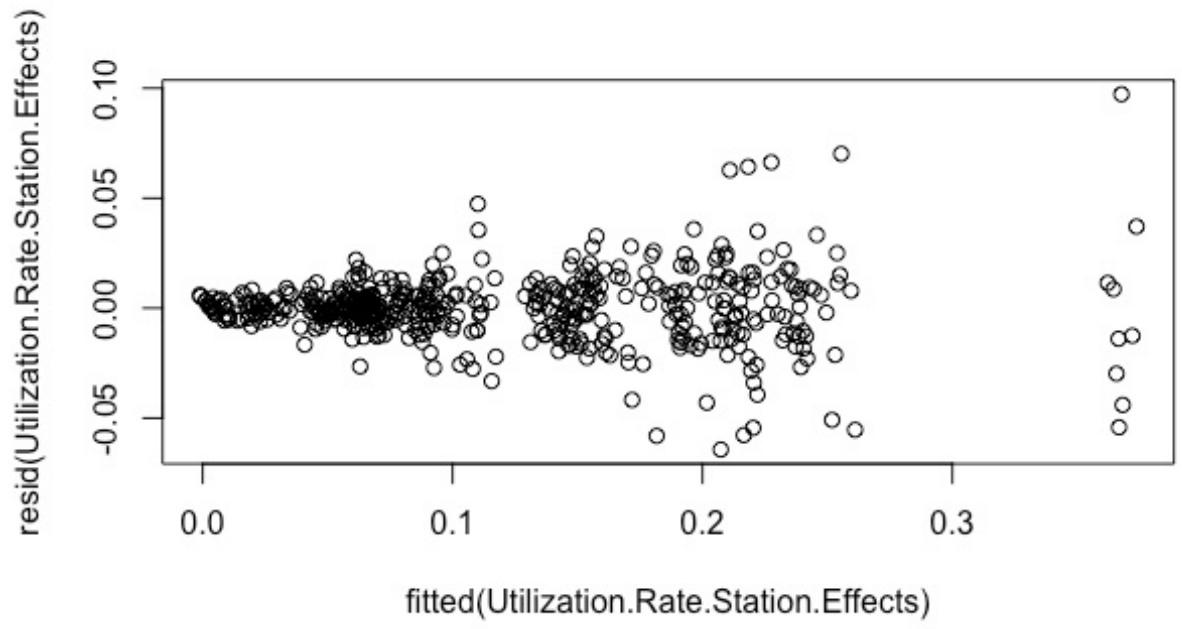

From the factors that proved to be statistically significant there are several trends and results that require specific explanation. There are two categories of built form and demographic factors that are affecting utilization, those that can be changed by a municipal government or transit agency and those that are more regional or large-scale factors and thus beyond the control of local transit and planning agencies. The factors that can be affected locally demonstrate what agencies can do to make station areas more transit supportive. In these models, parking capacity and household density are the easiest to manipulate locally. As discussed earlier, these two are not complementary and thus the incremental ridership effect and viability of increasing household density or increasing parking capacity at a station should be examined to best capitalize on increased capacity and serve the surrounding community. The other built form and demographic factors are not easily manipulated by a local planning or transit agency however they should be taken into account when developing models that predict which corridors should be prioritized for new capacity as they are more supportive of commuter rail services.

With the demographic and built form variables controlled for, station variables that were found to be significant can also be used to make recommendations for where to provide increased service or where there is existing unused capacity in the AM peak period. First, Lakeshore East, Lakeshore West, Stouffville, and Richmond Hill would generate new ridership from increased capacity based on overall positive coefficients for each line with the stations on the Barrie corridor (the bottom nine of Table 6) serving as a reference. However, the coefficient 
for each station is not positive which may indicate redistributing inbound service on a corridor to provide "express" trips to stations that have positive coefficients and are responsive to service increases. The other three corridors, Barrie, Kitchener, and Milton, all have unused capacity that could be more efficiently utilized before new capacity is added. The Barrie corridor stations were used a reference case in the regression model. Based on net positive or negative coefficients for each line the priority for AM service increases that would generate new ridership would be Lakeshore East, Lakeshore West, Stouffville, Richmond Hill, Barrie, Kitchener, and finally Milton. An evaluation of utilization on two-way all day services would provide further recommendations for where to target service improvements that would generate all day ridership.

The residual plot for model 3 shows a highly heteroskedastic distribution that is less reliable for explaining variation at stations with higher utilization rates (in both positive and negative directions) suggesting that other factors beyond the scope of this research may be impacting the utilization at the station level. As a consequence, coefficients can still be interpreted as is, but significance levels and standard errors should be interpreted cautiously.

Conclusions drawn from aggregating station results into corridors to evaluate underutilized capacity and unserved demand are still informative and may be similar with less heteroskedastic outputs and access to a broader selection of independent variables. Natural logging the dependent variable produced a lower $\mathrm{r}^{2}$ value and lowered the significance of each independent variable while heavily boosting the significance of the seasonal effects therefore the non-logged version of the model was more appropriate.

\section{4: Model 4}

Model 4 sought to explain the variables that impact year-over-year growth in utilization. The results of model are presented in Table 7 with a residual plot in Figure 12. 
Table 7: Output of Station-level Year-over-year Utilization Change Model (Model 4)

$\begin{array}{ccccc}\text { Min } & 1 \mathrm{Q} & \text { Median } & \text { 3Q } & \text { Max } \\ -0.57721 & -0.07361 & -0.00575 & 0.05938 & 0.50491\end{array}$

\begin{tabular}{|c|c|c|c|c|c|}
\hline Coefficients & Estimate & Std. & Error & t value & $\operatorname{Pr}(>|t|)$ \\
\hline (Intercept) & $1.15 \mathrm{E}+00$ & $2.52 \mathrm{E}-01$ & 4.566 & $6.32 \mathrm{E}-06$ & $* * *$ \\
\hline PERCIMMIGRANT & $9.00 \mathrm{E}-05$ & $1.22 \mathrm{E}-03$ & 0.074 & 0.94138 & \\
\hline EMPLOY_RTE & $-5.57 \mathrm{E}-04$ & $3.40 \mathrm{E}-03$ & -0.164 & 0.86976 & \\
\hline MED_INC & $-1.26 \mathrm{E}-06$ & $2.92 \mathrm{E}-06$ & -0.431 & 0.66687 & \\
\hline HH_DENS & $6.08 \mathrm{E}-06$ & $1.87 \mathrm{E}-05$ & 0.325 & 0.74534 & \\
\hline FREEPARK & $-6.05 \mathrm{E}-04$ & $1.35 \mathrm{E}-03$ & -0.449 & 0.65375 & \\
\hline WORKERS.HH & $-2.20 \mathrm{E}-02$ & $5.70 \mathrm{E}-02$ & -0.386 & 0.69992 & \\
\hline XOCAR & $-1.83 \mathrm{E}-03$ & $2.47 \mathrm{E}-03$ & -0.743 & 0.45806 & \\
\hline X1CAR & $-1.44 \mathrm{E}-03$ & $7.32 \mathrm{E}-04$ & -1.967 & 0.04972 & $*$ \\
\hline X2CAR & NA & NA & NA & NA & \\
\hline ParkingCapacity & $5.68 \mathrm{E}-06$ & $8.76 \mathrm{E}-06$ & 0.648 & 0.517 & \\
\hline TTC_Option & 4.17E-02 & $4.21 \mathrm{E}-02$ & 0.991 & 0.32218 & \\
\hline Terminal & $5.64 \mathrm{E}-02$ & $2.80 \mathrm{E}-02$ & 2.017 & 0.04424 & $*$ \\
\hline Lakeshore.West & $-3.77 \mathrm{E}-02$ & $3.30 \mathrm{E}-02$ & -1.142 & 0.25405 & \\
\hline Lakeshore.East & $-3.37 \mathrm{E}-02$ & $3.31 \mathrm{E}-02$ & -1.018 & 0.30936 & \\
\hline Kitchener & $-5.93 \mathrm{E}-02$ & $3.16 \mathrm{E}-02$ & -1.879 & 0.06086 & . \\
\hline Richmond.Hill & $-5.20 \mathrm{E}-02$ & 4.27E-02 & -1.218 & 0.22371 & \\
\hline Milton & $-3.23 \mathrm{E}-02$ & $3.08 \mathrm{E}-02$ & -1.049 & 0.29474 & \\
\hline Stouffville & $-2.76 \mathrm{E}-02$ & $3.40 \mathrm{E}-02$ & -0.814 & 0.41621 & \\
\hline Barrie & NA & NA & NA & NA & \\
\hline Fall.2010 & $1.55 \mathrm{E}-01$ & $2.59 \mathrm{E}-02$ & 5.977 & 4.46E-09 & $* * *$ \\
\hline Spring.2011 & $6.98 \mathrm{E}-02$ & $2.59 \mathrm{E}-02$ & 2.695 & 0.00728 & $* *$ \\
\hline Fall.2011 & 7.09E-02 & $2.58 \mathrm{E}-02$ & 2.752 & 0.00615 & $* *$ \\
\hline Spring.2012 & $8.22 \mathrm{E}-02$ & $2.56 \mathrm{E}-02$ & 3.208 & 0.00142 & $* *$ \\
\hline Fall.2012 & $7.80 \mathrm{E}-02$ & $2.55 \mathrm{E}-02$ & 3.06 & 0.00234 & $* *$ \\
\hline Spring.2013 & $4.61 \mathrm{E}-02$ & $2.55 \mathrm{E}-02$ & 1.807 & 0.07133 & . \\
\hline Fall.2013 & $1.65 \mathrm{E}-01$ & $2.52 \mathrm{E}-02$ & 6.578 & $1.26 \mathrm{E}-10$ & $* * *$ \\
\hline Fall.2014 & $1.31 \mathrm{E}-01$ & $2.47 \mathrm{E}-02$ & 5.306 & $1.72 \mathrm{E}-07$ & $* * *$ \\
\hline Spring. 2015 & NA & NA & NA & NA & \\
\hline
\end{tabular}

Signif. codes: 0 '***' 0.001 '**' 0.01 '*' 0.05 '? $0.1^{\text {‘ ' } 1}$

Residual standard error: 0.1363 on 477 degrees of freedom

Multiple R-squared: $0.1582, \quad$ Adjusted R-squared: 0.1141

F-statistic: 3.585 on 25 and 477 DF, p-value: $2.586 \mathrm{e}-08$ 
Figure 12: Residual Plot of Station-level Year-over-year Utilization Change Model (Model 4)

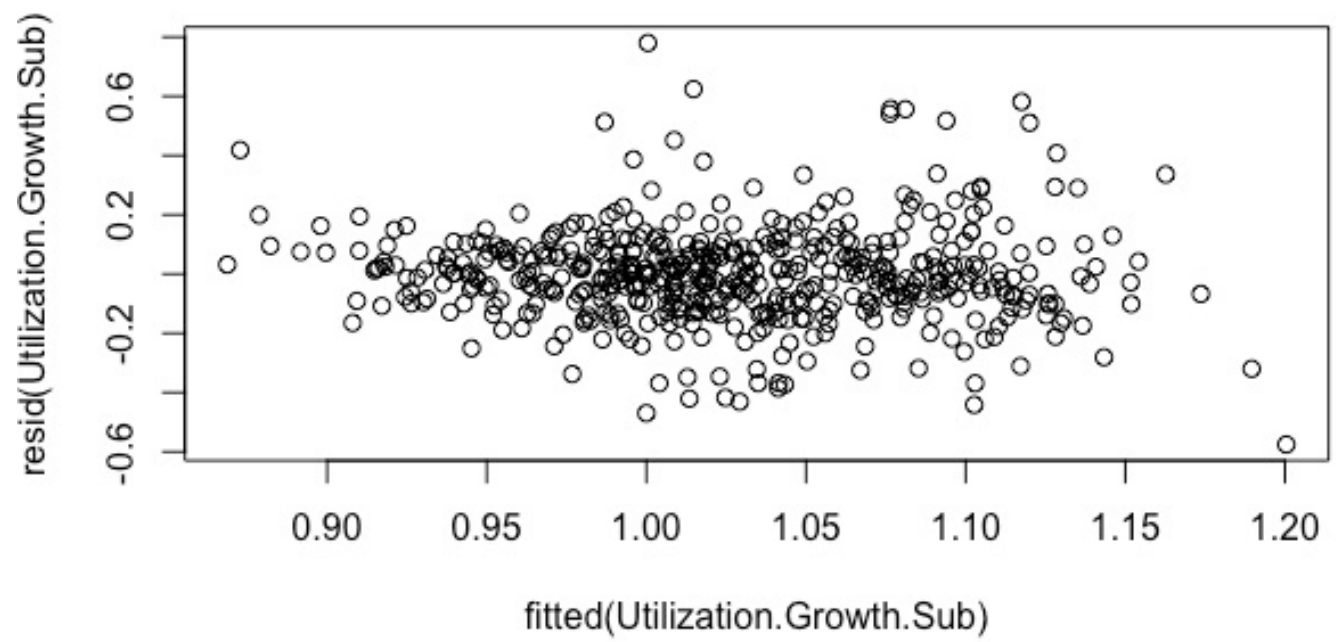

The low $r^{2}$ value of the model was indicative of other factors that affect year to year utilization changes and the significance of the fixed seasonal effects show that the year that the count was completed had a large impact on the observed utilization growth rate. The coefficients of the independent variables indicate which factors were supportive of utilization growth but few in a statistically significant way. Reading the coefficients of the variables and comparing them to other models provides an interesting look at the behaviour of riders and the impact of larger trends on utilization growth. The positive sign associated with terminal station utilization growth compared to a terminal's negative effect on average ridership and utilization (Model 1 and 2) hints at the behaviour of riders who take time to change their commuting habits as a result of service expansion or extension. If service is expanded to a new area, riders who accessed the system at the old terminal might be slow to change their access station because of familiarity with their current commuting routine.

The positive coefficient of the competing TTC service variable may be attributed to the weighting factor that downplayed the negative effect of competing service on station ridership as many of the GO stations near TTC subway stations had very low comparable numerical ridership to other stations on the network. The effect of parking capacity and 2 or more car households again supports the conclusion that ridership, and in this case growth in ridership based on the capacity provided, is significantly dependent on the availability of park and ride capacity. 
While the residual plot is distributed evenly the low $\mathrm{r}^{2}$ value and dominant seasonal effects show that there are other factors beyond those collected for this study that impact utilization growth. This model shows exploratory results that can be used to inform the future study of factors that can create areas more supportive of generating utilization of rail service capacity. 


\section{$\underline{7.0 \text { Conclusions }}$}

\subsection{Conclusions}

Based on the findings from this research and accounting for the overall trend in A.M. boardings on the GO Rail system and the demographic and built form factors of station areas there are several important conclusions for ridership, utilization, and year-over-year growth in utilization from tis research. Parking capacity has a large effect on station ridership and utilization and marginal increases in parking capacity could generate greater utilization of existing capacity. Building new parking or developing housing in surrounding areas should be carefully evaluated to determine the most effective way to generate utilization of existing capacity and achieve goals and targets set out by local and provincial plans. These decisions about land use will also impact the surrounding area and are subject to provincial and local plans that call for new residential and commercial growth to be concentrated around transit stations. Many of the more suburban stations will remain dependent on parking availability to generate AM ridership and utilization while building new housing units in station areas is not a contributor of increased ridership based on the findings of this research. Housing and population in close proximity to a station may be more significant in the future if traffic congestion worsens but the already ample supply of parking encourages automobiles access many stations and thus parking supply is a more significant factor in ridership.

Corridors were also evaluated based on their current utilization and ability to generate ridership from new capacity provided. In order of priority for new capacity investments the lines would be ranked: Lakeshore East, Lakeshore West, Stouffville, Richmond Hill, Barrie, Kitchener, and finally Milton. These findings are exploratory based on the performance of the model but can be used to inform future models that predict the response of particular corridors to increased capacity using a larger pool of data and a longer time period. This research also identified variables that influence commuter rail ridership and should be controlled for in any future study and modelling of commuter rail ridership in the Greater Toronto and Hamilton Area. The large effect of the cordon count days on the models developed may indicate the need for a different pattern of cordon counts that averages weekly boardings or reduces the time between cordon count days. 


\subsection{Limitations and Next Steps}

As the level of service frequency will be raised so dramatically on four of the seven GO Rail corridors it will be necessary to conduct further research on the factors affecting all-day ridership on these lines as the model developed in this study examined exclusively A.M. boardings. While this research has identified the impact of station area demographics on transit ridership there are other built form factors that should be evaluated for their effect on ridership such as street network density in the surrounding area, local feeder bus connections, walking and cycling catchment areas, and proximity to highways that would require a larger station area boundary to examine. Other factors that would predictably have an impact on commuter rail ridership and should be included in future research are travel time to the central station and locations of employment of residents within a TAZ.

The limit of a one-mile radius for station areas ay also present challenges when interpreting these results. Due to the large number of riders who access the station from further than one mile away, the socio-economic variables of the limited radius may not be representative of all the people who access GO Rail stations. Future research that involved a survey of commuters who are accessing GO Rail stations would be more descriptive of the people who are accessing transit.

There are also several constraints on the research based on the time of day evaluated. Behavioural impacts of people who alter their travel patterns based on the perceived reliability and comfort of rail service over bus service may "push" more riders to travel on AM or PM commuter trains where all-day services may spread out ridership beyond the AM peak period that was examined.

A more complete model would also evaluate the surrounding station area factors that affect the number of riders exiting at a particular station to build an understanding of demographic and built form factors affecting the station as a destination for transit trips. As data becomes available, the methods developed in this research could be used to evaluate operational service level changes to best utilize capacity for all-day boardings. Future research using the explanatory models from this research could be examined the relative ridership impacts of building parking structures or developing new housing around station areas in order to inform future land use policy directions. 


\subsection{Appendices}

Appendix 1: Station Capacity in Cordon Count Years

\begin{tabular}{|c|c|c|c|c|c|c|c|c|c|c|}
\hline & $\begin{array}{l}\text { Spring } \\
2010 \\
\end{array}$ & Fall 2010 & $\begin{array}{l}\text { Spring } \\
2011 \\
\end{array}$ & Fall 2011 & \begin{tabular}{|l|} 
Spring \\
2012 \\
\end{tabular} & Fall 2012 & \begin{tabular}{|l} 
Spring \\
2013 \\
\end{tabular} & $\begin{array}{l}\text { Fall } \\
2013 \\
\end{array}$ & \begin{tabular}{|l|} 
Fall \\
2014 \\
\end{tabular} & $\begin{array}{l}\text { Spring } \\
2015 \\
\end{array}$ \\
\hline Aldershot & 10798 & 11120 & 11120 & 11120 & 11120 & 11370 & 17864 & 17556 & 17864 & 17864 \\
\hline Burlington & 17138 & 17782 & 17782 & 17782 & 17782 & 17990 & 17864 & 17556 & 17864 & 17864 \\
\hline Appleby & 17138 & 17782 & 17782 & 17782 & 17782 & 17990 & 17864 & 17556 & 17864 & 17864 \\
\hline Bronte & 17138 & 17782 & 17782 & 17782 & 17782 & 17990 & 17864 & 17556 & 17864 & 17864 \\
\hline Oakville & 20308 & 20952 & 20952 & 22537 & 22537 & 22715 & 22484 & 22176 & 24024 & 24024 \\
\hline Clarkson & 16172 & 16816 & 16816 & 16816 & 16816 & 17030 & 16940 & 16632 & 18480 & 18480 \\
\hline Port Credit & 12680 & 13324 & 13324 & 13324 & 13324 & 13560 & 13244 & 12936 & 14784 & 14784 \\
\hline Long Branch & 11095 & 11417 & 11417 & 11417 & 11417 & 11665 & 11704 & 11396 & 13244 & 13244 \\
\hline Mimico & 11095 & 11417 & 11417 & 11417 & 11417 & 11665 & 11704 & 11396 & 13244 & 13244 \\
\hline Oshawa & 18401 & 18723 & 19045 & 19045 & 19045 & 18925 & 18480 & 16632 & 16632 & 16632 \\
\hline Whitby & 18401 & 18723 & 19045 & 19045 & 19045 & 18925 & 18480 & 16632 & 18172 & 18172 \\
\hline Ajax & 18401 & 18723 & 19045 & 19045 & 19045 & 18925 & 18480 & 16632 & 18172 & 18172 \\
\hline Pickering & 23156 & 23478 & 23800 & 23800 & 23800 & 23970 & 23408 & 21560 & 23100 & 23100 \\
\hline Rouge Hill & 14909 & 14587 & 14909 & 14909 & 14909 & 15135 & 14784 & 12936 & 12936 & 12936 \\
\hline Guildwood & 13002 & 13002 & 13324 & 13324 & 13324 & 13560 & 13244 & 11396 & 11396 & 11396 \\
\hline Eglinton & 13002 & 13002 & 13324 & 13324 & 13324 & 13560 & 13244 & 11396 & 11396 & 11396 \\
\hline Scarborough & 13002 & 13002 & 13324 & 13324 & 13324 & 13560 & 13244 & 11396 & 11396 & 11396 \\
\hline Danforth & 13002 & 13002 & 13324 & 13324 & 13324 & 13560 & 13244 & 11396 & 11396 & 11396 \\
\hline Georgetown & 6340 & 6340 & 6340 & 6340 & 7925 & 7875 & 7700 & 7700 & 9240 & 9240 \\
\hline Mount Pleasant & 6340 & 6340 & 6340 & 6340 & 7925 & 7875 & 7700 & 7700 & 10780 & 10780 \\
\hline Brampton & 6340 & 6340 & 6340 & 6340 & 7925 & 7875 & 7700 & 7700 & 10780 & 10780 \\
\hline Bramalea & 11095 & 11095 & 11095 & 11095 & 12680 & 12920 & 12628 & 12628 & 14168 & 13244 \\
\hline Malton & 9510 & 9510 & 9510 & 9510 & 11095 & 11345 & 11088 & 11088 & 12628 & 11704 \\
\hline $\begin{array}{l}\text { Etobicoke } \\
\text { North }\end{array}$ & 9510 & 9510 & 9510 & 9510 & 11095 & 11345 & 11088 & 11088 & 12628 & 11704 \\
\hline Weston & 9510 & 9510 & 9510 & 9510 & 11095 & 11345 & 11088 & 11088 & 12628 & 11704 \\
\hline Bloor & 9510 & 9510 & 9510 & 9510 & 11095 & 11345 & 11088 & 11088 & 12628 & 11704 \\
\hline Richmond Hill & 7925 & 7925 & 7925 & 7925 & 7925 & 6300 & 7700 & 7700 & 7700 & 7700 \\
\hline Langstaff & 7925 & 7925 & 7925 & 7925 & 7925 & 6300 & 7700 & 7700 & 7700 & 7700 \\
\hline Old Cummer & 7925 & 7925 & 7925 & 7925 & 7925 & 6300 & 7700 & 7700 & 7700 & 7700 \\
\hline Oriole & 7925 & 7925 & 7925 & 7925 & 7925 & 6300 & 7700 & 7700 & 7700 & 7700 \\
\hline
\end{tabular}




\begin{tabular}{|c|c|c|c|c|c|c|c|c|c|c|}
\hline Milton & 13349 & 13349 & 13349 & 13349 & 13349 & 15160 & 14784 & 14784 & 14784 & 16632 \\
\hline Lisgar & 13349 & 13349 & 13349 & 13349 & 13349 & 15160 & 14784 & 14784 & 14784 & 16632 \\
\hline Meadowvale & 13349 & 13349 & 13349 & 13349 & 13349 & 15160 & 14784 & 14784 & 14784 & 16632 \\
\hline Streetsville & 13349 & 13349 & 13349 & 13349 & 13349 & 15160 & 14784 & 14784 & 14784 & 16632 \\
\hline Erindale & 13349 & 13349 & 13349 & 13349 & 13349 & 15160 & 14784 & 14784 & 14784 & 16632 \\
\hline Cooksville & 13349 & 13349 & 13349 & 13349 & 13349 & 15160 & 14784 & 14784 & 14784 & 16632 \\
\hline Dixie & 13349 & 13349 & 13349 & 13349 & 13349 & 15160 & 14784 & 14784 & 14784 & 16632 \\
\hline Kipling & 13349 & 13349 & 13349 & 13349 & 13349 & 15160 & 14784 & 14784 & 14784 & 16632 \\
\hline Lincolnville & 7925 & 7925 & 7925 & 7925 & 7925 & 8835 & 11704 & 11704 & 10164 & 10164 \\
\hline Stouffville & 7925 & 7925 & 7925 & 7925 & 7925 & 8835 & 11704 & 11704 & 10164 & 10164 \\
\hline Mount Joy & 7925 & 7925 & 7925 & 7925 & 7925 & 8835 & 11704 & 11704 & 10164 & 10164 \\
\hline Markham & 7925 & 7925 & 7925 & 7925 & 7925 & 8835 & 11704 & 11704 & 10164 & 10164 \\
\hline Centennial & 7925 & 7925 & 7925 & 7925 & 7925 & 8835 & 11704 & 11704 & 10164 & 10164 \\
\hline Unionville & 7925 & 7925 & 7925 & 7925 & 7925 & 8835 & 11704 & 11704 & 11704 & 11704 \\
\hline Milliken & 6340 & 6340 & 6340 & 6340 & 6340 & 7260 & 10164 & 10164 & 11704 & 11704 \\
\hline Agincourt & 6340 & 6340 & 6340 & 6340 & 6340 & 7260 & 10164 & 10164 & 11704 & 11704 \\
\hline Kennedy & 6340 & 6340 & 6340 & 6340 & 6340 & 7260 & 10164 & 10164 & 11704 & 11704 \\
\hline Barrie South & 6340 & 6340 & 6340 & 7925 & 7925 & 8195 & 8008 & 8008 & 8316 & 8316 \\
\hline Bradford & 6340 & 6340 & 6340 & 7925 & 7925 & 8195 & 8008 & 8008 & 8316 & 8316 \\
\hline $\begin{array}{l}\text { East } \\
\text { Gwillambury }\end{array}$ & 6340 & 6340 & 6340 & 7925 & 7925 & 8195 & 8008 & 8008 & 8316 & 8316 \\
\hline Newmarket & 6340 & 6340 & 6340 & 7925 & 7925 & 8195 & 8008 & 8008 & 8316 & 8316 \\
\hline Aurora & 6340 & 6340 & 6340 & 7925 & 7925 & 8195 & 8008 & 8008 & 8316 & 8316 \\
\hline King City & 6340 & 6340 & 6340 & 7925 & 7925 & 8195 & 8008 & 8008 & 8316 & 8316 \\
\hline Maple & 6340 & 6340 & 6340 & 7925 & 7925 & 8195 & 8008 & 8008 & 9240 & 9240 \\
\hline Rutherford & 6340 & 6340 & 6340 & 7925 & 7925 & 8195 & 8008 & 8008 & 9240 & 9240 \\
\hline $\begin{array}{l}\text { York } \\
\text { University }\end{array}$ & 6340 & 6340 & 6340 & 7925 & 7925 & 8195 & 8008 & 8008 & 9240 & 9240 \\
\hline
\end{tabular}




\section{Appendix 2: Station Profiles for GO Rail Stations}

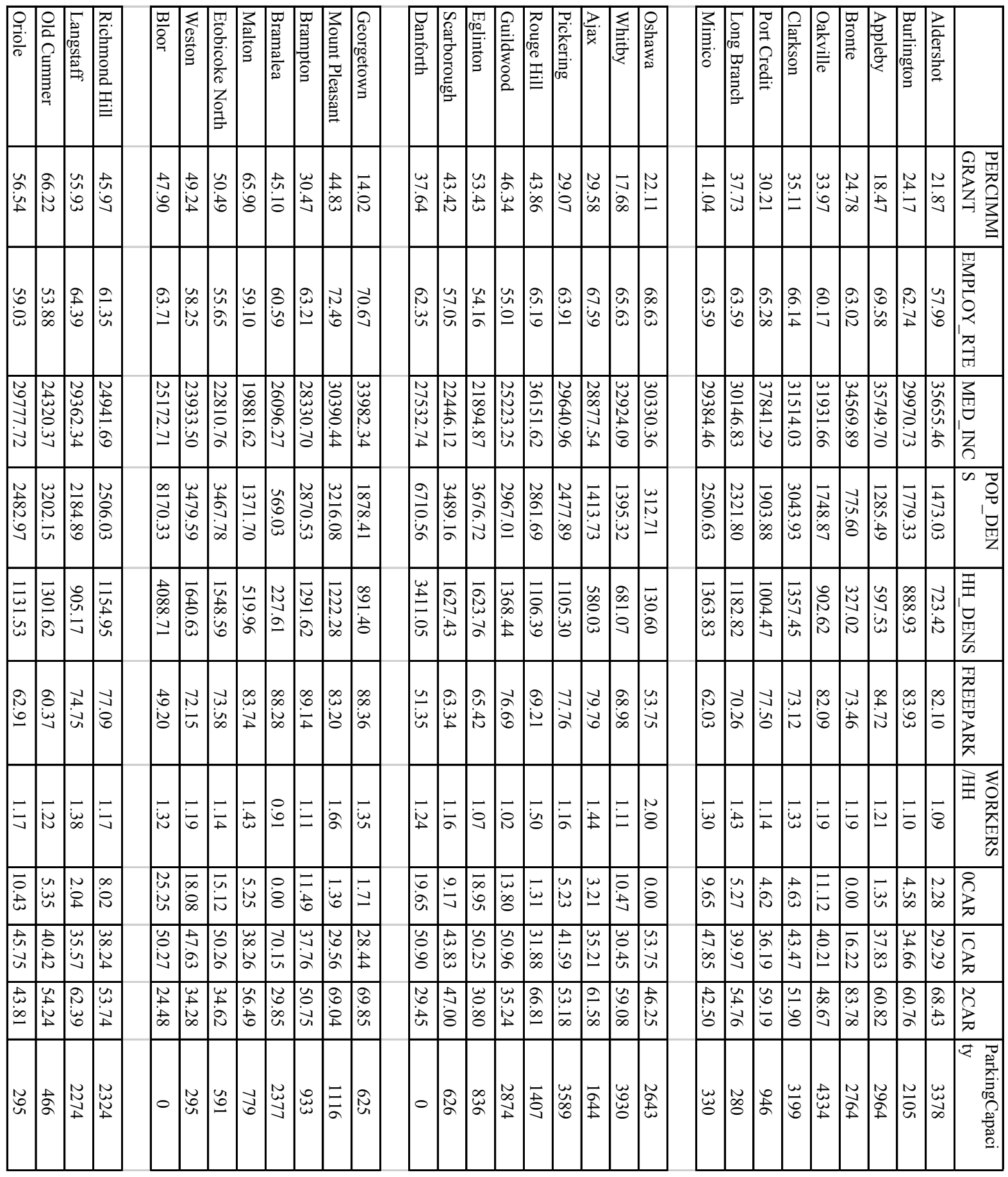




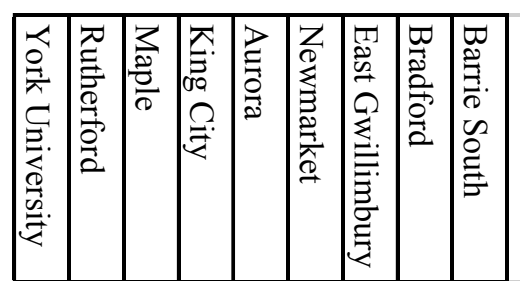

un

苮

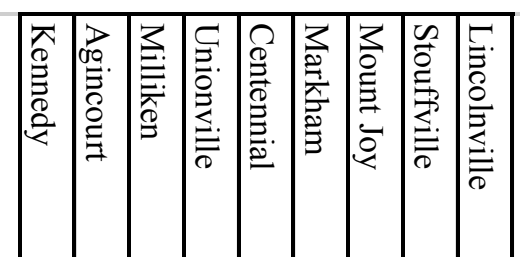

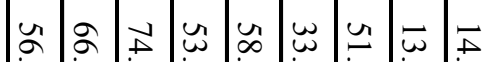

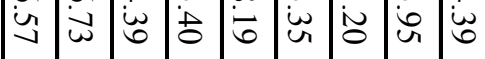

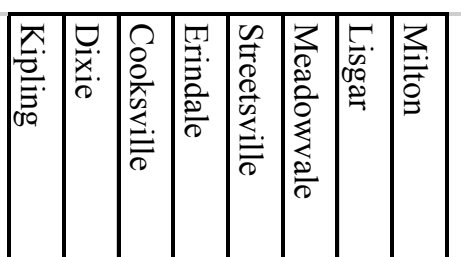

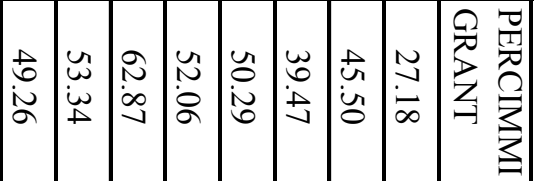

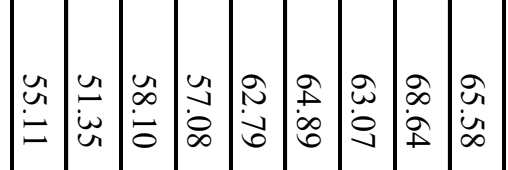

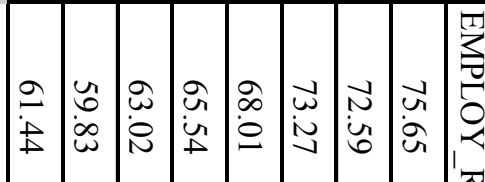

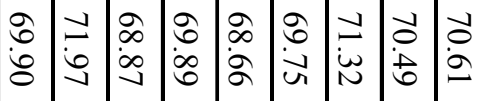

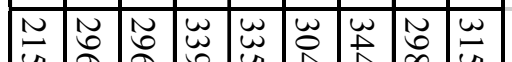

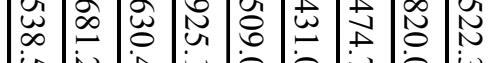

岁

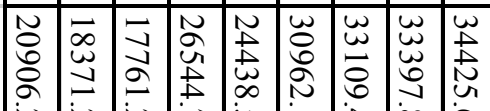

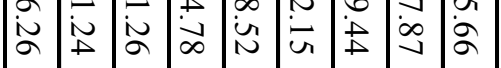

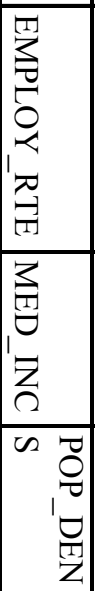

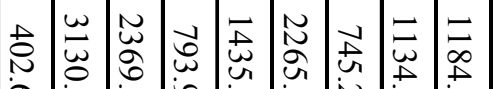

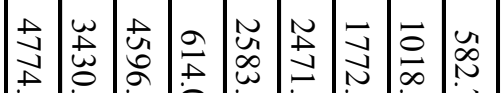

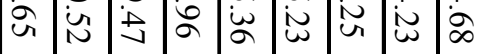

出

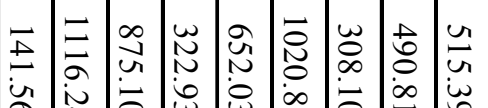

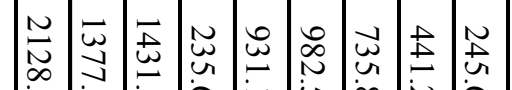

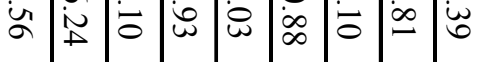

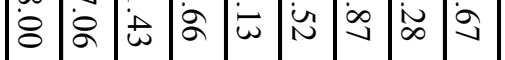

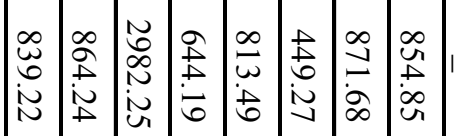

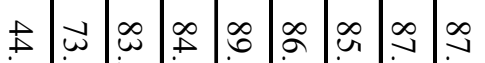

華

iิ ป

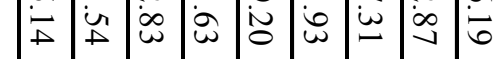

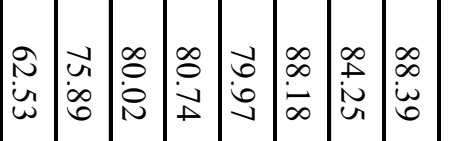

䞏

岕

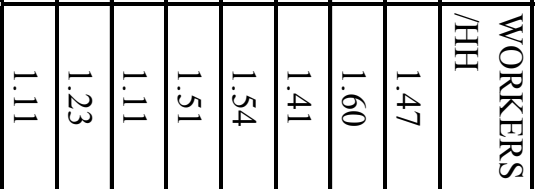

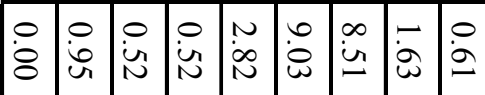

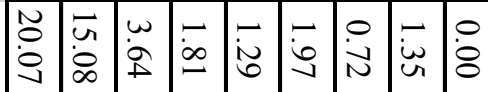

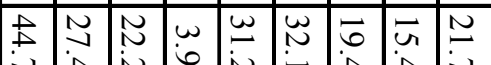

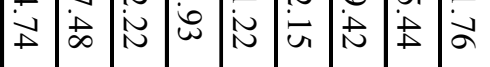

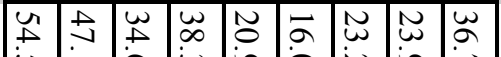

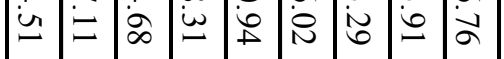

茂

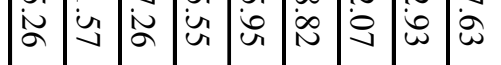

u

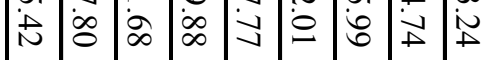

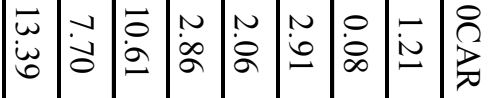

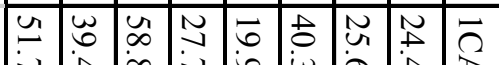

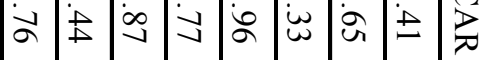

嵌

唄

-

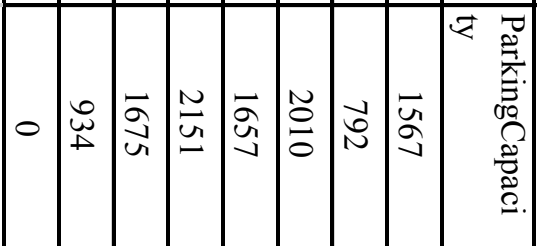




\subsection{References}

Badoe, D.A., \& Miller, E.J. (2000). Transportation-land-use interaction: Empirical findings in North America and their implications for modelling. Transportation Research Part D, 235-263.

Cervero, R. (2002). Built environments and mode choice: Toward a normative framework. Transportation Research Part D, 7, 262-284.

Cervero, R., \& Kockelman, K. (1997). Travel demand and the 3ds: Density, diversity, and design. Transportation Research D, 2(3), 199-219.

Chan, S., \& Miranda-Moreno, L. (2013). A station-level ridership model for the metro network in Montreal. Canadian Journal of Civil Engineering, 40, 254-262.

Chiang, W., Russell, R.A, \& Urban, T.L. (2011). Forecasting ridership for a metropolitan transit authority. Transportation Research Record Part A, 45, 696-705.

Chen, C., Varley, D., \& Chen, J. (2011). What affects transit ridership? A dynamic analysis involving multiple factors, lags, and asymmetric behaviour. Urban Studies, 48(9), 1893 1908.

Chiou, Y., Jou, R., \& Yang, C. (2015). Factors affecting public transit usage rate: Geographically weighted regression. Transportation Research Record Part A, 78, 161-177.

Crowley, D.F., Shalaby, A.S., \& Zarei, H. (2009). Access walking distance, transit use, and transit oriented development in North York city centre, Toronto, Ontario. Transportation Research Record, 2110, 96-105.

Dachis, B. (2013). Cars, congestion, and cost: A new approach to evaluating government infrastructure investment. CD Howe Commentary, 385.

Data Management Group. (2011). Transportation tomorrow survey: Internet data retrieval service. Retrieved form http://dmg.utoronto.ca/idrs.

Foth, N, Manaugh, K., \& El-Geneidy, A.M. (2014). Determinants of mode share over time: How changing transit system affects transit use in Toronto, Ontario, Canada. Transportation Research Record, 2417, 67-77.

Garcia, D., \& Bow, J. (2015). GO Transit's Lakeshore line. Retrieved from http://transit.toronto.on.ca/regional/2101.shtml.

GO Transit. (2016). GO Train Map, Retrieved from http://www.gotransit.com/timetables/en /schedules/maps.aspx\#. 
Government of Ontario. (2015). Ontario increasing GO Transit Service along all corridors (News release). Retrieved from http://news.ontario.ca/opo/en/2015/04/ontario-increasinggo-transit-service-along-all-corridors.html.

Gutierrez, J., Cardozo, O.D., \& Garcia-Palomares, J.C. (2011). Transit ridership forecasting at station level: An approach based on distance-decay weighted regression. Journal of Transport Geography, 19, 1081-1092.

HDR Corporation Decision Economics. (2008). Costs of road congestion in the Greater Toronto and Hamilton area: Impact and cost benefit analysis of the Metrolinx regional transportation plan. Retrieved from http://www.metrolinx.com/en/regionalplanning/ costsofcongestion/ISP_08-015_Cost_of_Congestion_report_1128081.pdf.

Jun, M., Choi, K., Jeong, J., Kwon, K., \& Kim, H. (2015). Land use characteristics of subway catchment areas and their influence on transit ridership in Seoul. Journal of Transport Geography, 48, 30-40.

Kalinowski, T. (2015, Aug 7). GO to boost train service on Kitchener, Stouffville lines, The Toronto Star, retrieved from http://www.thestar.com/news/gta/transportation/2015/08/07 /go-to-boost-train-service-on-kitchener-stouffville-lines.html.

Kohn, H.M. (2000). Factors affecting urban transit ridership. Statistics Canada Report (53F0003-XIE). Retrieved from http://www.publications.gc.ca/Collection/Statcan/ 53F0003X/53F0003XIE.pdf.

Kuby, M., Barranda, A., \& Upchurch, C. (2004). Factors influencing light-rail station boardings in the United States. Transportation Research Record Part A, 38, 223-247.

Kwoka, G.J., Boschmann, \& E.E., Goetz, A.R. (2015). The impact of transit station areas on travel behaviour of workers in Denver, Colorado. Transportation Research Part A, 277287.

Lane, C., DiCarlantonio, M., \& Uvyat, L. (2006). Sketch models to forecast commuter and light rail ridership: Update to TCRP report 16. Transportation Research Record, 1986, 198210.

Metrolinx. (2011). Mobility hub guidelines. Retrieved from http://www.metrolinx.com/en/ projectsandprograms/mobilityhubs/mobility_hub_guidelines.aspx.

Metrolinx. (2014). Regional Express Rail (RER). Retrieved from http://www.metrolinx.com/en/ docs/pdf/board_agenda/20140905/20140905_BoardMtg_Regional_Express_Rail_EN.pdf

Metrolinx. (2016). Metrolinx Overview. Retrieved from http://www.metrolinx.com/en/aboutus /metrolinxoverview/metrolinx_overview.aspx. 
Ministry of Transportation of Ontario. (2012). Transit-supportive guidelines. Retrieved from http://www.mto.gov.on.ca/english/transit/supportive-guidelines.shtml.

Ministry of Transportation of Ontario. (2015). Ontario improving GO Transit service along all corridors. Retrieved from https://news.ontario.ca/mto/en/2015/04/ontario-improving-gotransit-service-along-all-corridors.html.

Moniruzzaman, M., \& Paez, A. (2012). Accessibility to transit, by transit, and mode share: Application of a logistic model with spatial filters. Journal of Transport Geography, 24, 198-205.

Taylor, B.D, \& Fink, C.N. (2003). The factors affecting transit ridership: A review and analysis of ridership literature. Working Paper. Retrieved from http:/www.uctc.net/research/ papers/681.pdf.

Taylor, B., Miller, D., Iseki, H., \& Fink, C. (2009). Nature and/or nurture? Analyzing the determinants of transit ridership across US urbanized areas. Transportation Research Record Part A, 43, 60-77.

Thompson, G.L, \& Brown, J.R. (2006). Explaining variation in transit ridership in U.S. metropolitan areas between 1990-2000. Transportation Research Record, 1986, 172-181.

Thompson, G., Brown, J., \& Bhattacharya, T. (2012). What really matters for increasing transit ridership: Understanding the demand for transit ridership demand in Broward County, Florida. Urban Studies, 49(15), 3327-3345.

Voith, R. (1997). Fares, service levels, and demographics: What determines commuter rail ridership in the long run. Journal of Urban Economics. 41, 176-197.

Wells, S.S., \& Hutchinson, B.G. (1996). Impact of commuter rail services in Toronto region. Journal of Transportation Engineering, 122(4), 270-275.

Yao, X. (2007). Where are public transit needed - examining potential demand for public transit for commuting trips. Computers, Science, and Urban Systems, 31, 535-550.

Zahabi, S.A, Miranda-Moreno, L., \& Patterson, Z. (2012). Evaluating the effects of land use and strategies for parking and transit supply on mode choice of downtown commuters. Journal of Transport and Land Use, 5(2), 103-119. 